Agnieszka Lubera

Muzeum Narodowe w Krakowie, Kraków, Polska

alubera@mnk.pl

ORCID 0000-0002-5265-5311

\title{
Kalendarze z kolekcji Ignacego Wolskiego w zbiorach Muzeum Narodowego w Krakowie
}

\author{
Abstract \\ The calendars from Ignacy Wolski in the collection of \\ the National Museum in Krakow
}

A small but valuable collection of calendars was donated to the National Museum in Krakow in 1896, 1898 and 1906 by Ignacy Wolski, a Warsaw bibliophile. In the article an overview of these publications is given for the first time. The donation consists of calendars diverse in form and content, published from the end of the $18^{\text {th }}$ century to the early $20^{\text {th }}$ century. Only ten of them were found during the research in the Museum. Most of the preserved calendars was marked with characteristic provenance stamps or stickers;a part of them has some historical notes written by Wolski. They are a great testimony of the past. Wolski's motifs and idea behind collecting calendars and leaving these publications for future generations in the Museum were also presented in the article.

Key words: Ignacy Wolski - National Museum in Krakow - calendars - private collections donations $-19^{\text {th }}-20^{\text {th }}$ centuries.

Słowa kluczowe: Ignacy Wolski - Muzeum Narodowe w Krakowie - kalendarze - kolekcje prywatne - dary - XVIII-XX w.

„Z Badań nad Książką i Księgozbiorami Historycznymi” - Udział zagranicznych recenzentów w ocenie publikacji; Stworzenie anglojęzycznej wersji wydawniczej publikacji; Digitalizacja tomów archiwalnych rocznika w celu zapewnienia otwartego dostępu do nich przez Internet oraz wdrożenie i utrzymanie cyfrowej platformy redakcyjnej - zadanie finansowane w ramach umowy nr 653/P-DUN/2019 ze środków Ministra Nauki i Szkolnictwa Wyższego przeznaczonych na działalność upowszechniającą naukę. 
W zbiorach Muzeum Narodowego w Krakowie znajduje się niewielki, ale bardzo ciekawy zespół kalendarzy pochodzących z daru Ignacego Antoniego Wolskiego (ok. 1840-1913) ${ }^{1}$. Ten warszawski urzędnik i wytrawny kolekcjoner zgromadził w ciągu swojego życia szereg pamiątek polskiej przeszłości, od drobnej rzeźby portretowej i zabytków medalierstwa, przez bogate zbiory grafiki oraz kartografii, po księgozbiór liczący prawie 900 woluminów ${ }^{2}$. Z woli hojnego ofiarodawcy były one przekazywane krakowskiej instytucji stopniowo między 1896 a 1913 r., wzbogacając jej kolekcję poloniców jako wyraz głębokiego patriotyzmu donatora. Stanowiły zarazem cenny materiał dziejowy, świadczący o umiłowaniu Ojczyzny i - jak wiele inicjatyw kolekcjonerskich $\mathrm{w}$ tym czasie - nastawiony na ocalenie rodzimej kultury przed agresywną polityką zaborczą. Zgromadzone przez Wolskiego kalendarze również wpisywały się w ten nurt zbieractwa.

Kalendarze drukowane, których historia sięga końca XV w., miały charakter przede wszystkim praktyczny. Uzupełniane prognostykami astrologicznymi i pogodowymi, poradami gospodarskimi, medycznymi, obyczajowymi, informacjami politycznymi, utworami literackimi czy artykułami historycznymi były bardzo chętnie wykorzystywane w życiu codziennym przez grupy odbiorców, do których były adresowane ${ }^{3}$. W Polsce w okresie zaborów kalendarze nabrały szczególnego znaczenia, służąc krzewieniu ducha narodowego i stając się środkiem umacniającym narodową tożsamość. Wskazywali na to autorzy wystawy „Zegar bije - czas ucieka”:

W okresie porozbiorowym kalendarze ukazywały się w każdym zaborze osobno. Mimo ścisłych kontroli ze strony zaborców, stanowiły wydawnictwa, które obok pełnionych we wcześniejszych wiekach funkcji, budziły i utrzymywały polskość, szerzyły przywiązanie do języka polskiego, narodowych obyczajów, historii kraju ${ }^{4}$.

Ze względu na wyznaczone im zadania, kalendarze cieszyły się ogromną popularnością. Jednocześnie jednak szybko traciły na aktualności, ulegały zniszczeniu i były sukcesywnie zastępowane bieżącymi rocznikami. $\mathrm{Z}$ tej przyczyny zachowane do dziś zbiory wydawnictw kalendarzowych nie są

1 A. Lubera, Ignacy Wolski-zapomniany darczyńca Muzeum Narodowego w Krakowie, „Rozprawy Muzeum Narodowego w Krakowie" 2018, t. 12, s. 170-178.

2 Taż, Dary biblioteczne Ignacego Wolskiego dla Muzeum Narodowego w Krakowie, [w:] Ksiażka i biblioteki na przestrzeni wieków. Materiały z konferencji naukowej, Katowice, 23 maja $2018 r$. (w przygotowaniu).

3 B. Rok, Kalendarz, [w:] Encyklopedia książki. T. 2: K-Z, red. A. Żbikowska-Migoń, M. Skalska-Zlat, Wrocław 2017, s. 23-25. U progu XX w. obszerny artykuł na temat kalendarza zamieścił Zygmunt Gloger w swojej Encyklopedii staropolskiej ilustrowanej (t. 2, Warszawa 1901, s. 306-316).

4 K. Kosior, D. Matyjasek, ,Zegar bije - czas ucieka...” Z dziejów zegara i polskiego kalendarza. Wystawa w Muzeum Podlaskim w Białymstoku, październik-grudzień 2008, Białystok 2008, s. [3]. Por. E. Wójcik, Kalendarze dwudziestolecia międzywojennego (dzieje, problemy literatury i kultury, bibliografia), Kraków 2000, s. 22, 25. 
kompletne i stwarzają dużą trudność w rejestracji bibliograficznej. O potrzebie stworzenia pełnej ewidencji wydawanych w Polsce kalendarzy przekonywali już Władysław i Wojciech Chojnaccy5. Niniejszy artykuł jest skromną odpowiedzią na postulat wspomnianych badaczy, gdyż autorka objęła rozważaniem naukowym kolekcję należącą do osoby prywatnej: dziesięć kalendarzy I. Wolskiego, przechowywanych obecnie w różnych działach Muzeum Narodowego w Krakowie (Dział Starych Druków, Rękopisów i Kartografii - pięć obiektów, Biblioteka MNK - dwa obiekty, Gabinet Grafiki i Rysunku - trzy obiekty ${ }^{6}$.

$\mathrm{Z}$ dokumentacji muzealnej wiadomo ponadto o darowaniu przez kolekcjonera jeszcze kilku wydawnictw tego typu. Podczas kwerendy nie udało się odnaleźć warszawskiego „Kalendarza domowego na rok zwyczajny 1831” Antoniego Gałęzowskiego i Komp., ,,Rocznika urzędowego obejmującego spis naczelnych władz cesarstwa oraz spis wszelkich władz i urzędników Królestwa Polskiego na rok 1860”, „Kalendarza ułożonego z dziejów stuletniej walki narodu polskiego o niepodległość" (rękopis) oraz czterech kalendarzy fotograficznych z lat 1866, 1867, 1868 i 1869, wykonanych przez Zakład Konrada Brandla i Spółki w Warszawie ${ }^{7}$. Poza zapisami inwentarzowymi, oznaczonymi w dwóch przypadkach pieczątkami ze skontrum przeprowadzonego na początku lat 50. XX w., brakuje jakichkolwiek śladów obecności tych obiektów w Muzeum w późniejszym okresie.

Zachowane almanachy (łac. almanachus, od arab. al manákh - kalendarz) z kolekcji Wolskiego, ofiarowane Muzeum w 1896, 1898 oraz 1906 r., charakteryzują się dużą różnorodnością ${ }^{8}$. Występuje tu zarówno siedem mniej lub bardziej obszernych wydawnictw książkowych o niewielkich formatach, jak i trzy znacznych rozmiarów jednoplanszowe kalendarze ścienne, $w$ tym jeden blankiet chromolitograficzny przygotowany w krakowskiej Drukarni „Czasu” pod kalendarz na rok 1861. Spora jest też rozpiętość chronologiczna omawianego zbioru. Obejmuje on bowiem trzy stare druki z ostatniej dekady XVIII w., pięć publikacji XIX-wiecznych oraz dwie pozycje z początku XX stulecia. Najstarszy kalendarz wydano na rok 1792 (,Königl. grosbritannischer historischer genealogischer Calender”), najmłodsze natomiast - „Przedświt” i „Kalendarz polski historyczny popularny religijno-moralny" - zapewne towarzyszyły

W. Chojnacki, W. Chojnacki, Bibliografia kalendarzy polonijnych 1838-1982, Wrocław 1984, s. 6-8; Bibliografia kalendarzy wydanych w języku polskim poza granicami Polski od roku 1716 (Mazury, Ślask Górny i Dolny oraz Ślask Cieszyński), Wrocław 1986, s. 8.

6 Za pomoc udzieloną podczas kwerend oraz pisania niniejszego artykułu serdecznie dziękuję pracownikom Muzeum Narodowego w Krakowie: paniom Iwonie Długopolskiej, Agnieszce Góreckiej-Maturze, Halinie Marcinkowskiej, Małgorzacie Myśliwiec-Łach, Agnieszce Perzanowskiej oraz Katarzynie Podniesińskiej.

7 Inwentarz Muzeum Narodowego w Krakowie, nr 10122, 10192-10195, 10210, 10245.

8 Dokładny opis zawartości i indywidualnych cech konkretnych egzemplarzy zamieszczono w katalogu na końcu artykułu. 
Wolskiemu jeszcze w 1906 r. Ze względu na zasięg terytorialny oraz językowy można wyróżnić dwa almanachy pochodzące $\mathrm{z}$ oficyn zagranicznych (Lauenburg/Frankfurt nad Menem, Berlin), jeden opublikowany po niemiecku, a drugi w języku francuskim. Pozostałe kalendarze ukazały się w polskiej wersji językowej w Warszawie lub Krakowie, głównych ośrodkach wydawniczych zaboru rosyjskiego i austriackiego.

Wszystkie znane autorce kalendarze mają średni lub dobry stan zachowania. Pozycje książkowe zostały oprawione w pergamin, karton, tekturę, skórę, półskórek lub płótno i opatrzone znakami własnościowymi. Stare druki oraz almanachy XIX-wieczne posiadają niewielką naklejkę: „No. [...] Ze zbiorów Ign. Wolskiego DAR TEGOŻ dla Muzeum Narodowego w Krakowie 1898 r.”, wskazującą na proweniencję, numer pozycji w biblioteczce ofiarodawcy oraz datę donacji. Natomiast egzemplarze wydane w ubiegłym stuleciu oznaczono pieczątką tuszową o następującej treści: „Muzeum Narodowe z daru Ignacego Wolskiego". Wśród kalendarzy wydrukowanych w postaci kodeksu pojawiają się publikacje interfoliowane z polecenia właściciela, zawierające jego rękopiśmienne notatki. Była to częsta praktyka stosowana przez wydawców lub samych użytkowników w celu umożliwienia sporządzania na dodatkowych czystych kartach dokumentacji życia rodzinnego czy zapisywania bieżących wydatków ${ }^{9}$. Notatki te są świadectwem dawnych czasów, „pozwalają poznać [...] mentalność właścicieli - przedstawicieli różnych kręgów społecznych"10 i - zdaniem Barbary Górskiej - ,podnoszą wartość kalendarza jako dokumentu epoki"11.

Charakteryzując niewielki zbiór kalendarzy warszawskiego darczyńcy zastosowano układ chronologiczny dla wydawnictw książkowych (z podziałem na publikacje zagraniczne i polskie) oraz układ terytorialny według miejsca powstania (Kraków, Warszawa) dla omawianych w dalszej części artykułu kalendarzy ściennych, zaliczanych często ze względu na swój profil artystyczny do produkcji graficznej.

Zatem najwcześniejszym almanachem-kodeksem, noszącym zarazem ślady użytkowania, jest wspomniany już „Königl. grosbritannischer historischer genealogischer Calender für 1792", stanowiący wspólne wydanie Eberharda Berenberga w Lauenburgu oraz Księgarni Jägera we Frankfurcie nad Menem. Co ciekawe, poza oryginalną kartą tytułową ze sceną alegoryczną rytowaną przez Friedricha Ludwiga Neubauera (1767-1828) według rysunku Daniela Chodowieckiego (1726-1801) ${ }^{12}$, kalendarz ten posiada drugą kartę w języku

9 B. Rok, dz. cyt., s. 25.

10 Tamże.

11 B. Górska, Katalog kalendarzy XVII-XVIII w. w zbiorach Biblioteki Ossolińskich, Wrocław 1968, s. VIII.

12 Wydawca powtórnie wykorzystał sztychowaną kartę tytułową zamieszczoną we wcześniej- 
polskim, wykonaną na zlecenie Wolskiego (fot. 1-2). Polska wersja tytułu brzmi: „Królewsko-Wielko-Brytański, Historyczno-Genealogiczny Kalendarz, na rok 1792, z rysunkami najnowszych ówczesnych mód i miedziorytami [sic!] Chodowieckiego, przedstawiającymi śmierć, wszystkie stany ludzi zabierającą". Pod podpisami do 12 zamieszczonych wewnątrz tekstu sztychów artysty również znalazły się polskie tłumaczenia pisane ołówkiem ręką I. Wolskiego.

Omawiany almanach, nienotowany w polskich zbiorach ${ }^{13}$, poza właściwą częścią kalendarzową obejmuje genealogię europejskich rodzin panujących, wiadomości historyczne, geograficzne i przyrodnicze, artykuły naukowe, jak Porównanie termometrów, oraz popularne, na przykład $O$ czułości, a także praktyczne zestawiania targów i jarmarków czy rozkładów pocztowych. Tekst poświęcony modzie zilustrowany został przedstawieniami współczesnych strojów, fryzur oraz damskimi nakryciami głowy. Całość kalendarza wyróżniają piękne ryciny autorstwa D. Chodowieckiego zogniskowane wokół motywu danse macabre (fot. 3). Realistycznie potraktowany kościotrup zaprasza do tańca śmierci przedstawicieli wszystkich stanów i zawodów: króla, matkę, żebraka, arystokratę, dziecko, żołnierza, generała, dziewczynę lekkich obyczajów, handlarkę ryb, papieża, królową, lekarza ${ }^{14}$. Niewykluczone, że to za przyczyną znakomitych akwafort frankfurcki almanach trafił do kolekcji Wolskiego, gromadzącego również chętnie wytwory graficzne.

Chodowiecki był niezwykle popularnym i cenionym rytownikiem, urodzonym w Gdańsku w rodzinie kupieckiej, ale kształcącym się i pracującym przez większość życia w Berlinie. Zajmował się przede wszystkim ilustracją książkową, w której osiągnął prawdziwe mistrzostwo, wprowadzając rozwiązania charakterystyczne dla stylu francuskiego rokoka. Jego sceny rodzajowe zachwycają lekkością, wdziękiem, oryginalną kompozycją oraz starannością wykonania, na co zwracano uwagę już w XVIII w. ${ }^{15}$ Niemiecki pisarz Johann

szej edycji tego kalendarza z roku 1779 , zmieniając jedynie dane bibliograficzne. Por. K. Zabuska, Zbiory Muzeum Narodowego w Gdańsku. Kolekcja Jacoba Kabruna. Ryciny szkoły niemieckiej od końca XV do początku XIX wieku. Cz. 2: Ryciny Daniela Chodowieckiego, Gdańsk 2015, s. 182.

13 K. Kłodzińska, Katalog kalendarzy od XVI do XVIII w. w zbiorach Biblioteki Kórnickiej, „Pamiętnik Biblioteki Kórnickiej” 1963, z. 8, s. 176-297; B. Górska, dz. cyt.; M. Paterak, Stare kalendarze i almanachy w zbiorach Biblioteki Muzeum-Zamku w Łańcucie. Katalog, Łańcut 1978. Brak informacji o obecności almanachu w zbiorach polskich stwierdzono także kierując zapytanie do Centralnego Katalogu Starych Druków Biblioteki Narodowej w Warszawie.

14 W. Engelmann, Daniel Chodowiecki's sämmtliche Kupferstiche. Beschrieben, mit historischen, literarischen und bibliographischen Nachweisungen, der Lebensbeschreibung des Künstlers und Registern versehen, Leipzig 1857, poz. 662; W. Prajer, Katalog rycin Daniela Chodowieckiego znajdujących się w Muzeum Narodowym w Krakowie, Kraków 1902, s. 71-72. Temat przemijania oraz kresu życia człowieka często pojawiał się w kalendarzach. Por. M. Krzysztofik, Kategoria czasu antropologicznego w polskim kalendarzu XVII-wiecznym, [w:] Kalendarze staropolskie, red. I.M. Dacka-Górzyńska, J. Partyka, Warszawa 2013, s. 79-86.

15 I. Dunikowska, Grafika Daniela Chodowieckiego w zbiorach Muzeum-Zamku w Łańcucie. 
Wilhelm Ludwig Gleim (1719-1803) miał powiedzieć: „Gdyby Chodowieckiego nie było, wiele z naszych książek nie byłoby przeczytanych"16. Natomiast sam artysta, który planował dla siebie inny rodzaj kariery pisał do matki: „Chciałem zostać malarzem, ale publiczność chce, bym został rytownikiem"

Chodowiecki przez ponad 30 lat regularnie współpracował z niemieckimi wydawcami kalendarzy, wykonując dla nich serie małoformatowych rycin o różnorodnej tematyce ${ }^{18}$. Jako pierwszy wprowadzał do tych poczytnych książeczek treści poważne, doniosłe, zgodne z ideałami epoki oświecenia ${ }^{19}$. Ilustrował między innymi słynny „Almanach de Gotha” oraz berliński „Almanach historique et généalogique", którego egzemplarz z 1798 r. posiadał I. Wolski. Wydany u Jana Fryderyka Ungra (1753-1804) zawiera studia historyczne nad życiem Katarzyny II oraz portrety, widoki, wizerunki medali i sceny związane $\mathrm{z}$ jej panowaniem. Pod względem zakresu treściowego, podobnie jak edycja Berenberga i Jägera, spełnia wymogi typowego dla tego okresu kalendarza historyczno-genealogicznego.

Do lektury wprowadza czytelnika całostronicowa rytowana alegoria rządów rosyjskiej cesarzowej. Na miniaturach portretowych poza samą władczynią przedstawiono carów Piotra III i Pawła I, a także osoby z jej bliskiego otoczenia: generała Aleksieja Orłowa (1737-1808), polityka Nikitę Panina (17181783), feldmarszałka Grigorija Potiomkina (1739-1791) oraz Aleksandra Suworowa (1729-1800), naczelnego wodza armii Imperium Rosyjskiego. Medale natomiast upamiętniają społeczne i polityczne sukcesy Katarzyny II, jak otwarcie domu dla sierot w Moskwie (1763), zakończenie wojny z Turcją (1774) czy podpisanie pokoju ze Szwecją (1790). Znalazł się wśród nich również medal autorstwa Johanna Balthasara Gassa (1730-1813) poświęcony osobie chirurga ogólnego i marszałka polnego Georga Thomasa von Ascha (1729-1807), który wsławił się walką z epidemią dżumy w czasie wojny rosyjsko-tureckiej ${ }^{20}$.

Wykonawcami wspomnianych rycin portretowych oraz wizerunków medali byli między innymi Johann Meno Haas (1752-1833) oraz Wilhelm Arndt (1750-1813). Prawdziwą ozdobą omawianego kalendarza jest jednak seria ośmiu sztychów D. Chodowieckiego ukazujących wybrane wydarzenia z życia i panowania Katarzyny II (fot. 4). Artysta przedstawił cesarzową w trakcie wizyty w zakładzie wychowawczym dla dziewcząt, składającą na grobie

\footnotetext{
Katalog wystawy, Łańcut 1972, s. 4-19.

16 Cyt. za: tamże, s. 19.

17 Cyt. za: K. Zabuska, Daniela Chodowieckiego przypadki. Rzecz o artyście spetnionym z Gdańskiem i Berlinem w tle, Gdańsk 2018, s. 122.

18 I. Dunikowska, dz. cyt., s. 15.

19 K. Zabuska, Zbiory Muzeum Narodowego w Gdańsku ..., s. 17, 21.

20 Û.B. Iversen, Medali v čest russkih gosudarstvennyh deâtelej i častnyh lic. T. 1, Sanktpeterburg 1880, s. 15-16.
} 
Piotra I Wielkiego flagi zdobyte na Turkach przez generała A. Orłowa, podczas przyjęcia wydanego u G. Potiomkina oraz podróżującą saniami do Chersonu. Pozostałe grafiki prezentują pochód carskiego orszaku do pałacu w Peterhofie, ucieczkę Kałmuków przez górskie wąwozy przed uciskiem ze strony władz rosyjskich, uroczyste odsłonięcie konnego pomnika Piotra I w Petersburgu oraz scenę nocną z obozu A. Suworowa rozbitego pod Pragą. Zwyczajem rytownika, wszystkie ilustracje posiadają teksty objaśniające równolegle w języku niemieckim i francuskim ${ }^{21}$.

Pomiędzy kartami „Almanach historique et généalogique pour l'année commune 1798" odnaleziono na luźnej fiszce zwięzłą notatkę I. Wolskiego: „Kalendarzyk z rycinami Daniela Chodowieckiego”, potwierdzającą uznanie kolekcjonera dla twórczości tego artysty. Podobnie jak w przypadku „Königl. grosbritannischer historischer genealogischer Calender für 1792", bibliofil zaopatrzył swój egzemplarz berlińskiego almanachu w polską wersję karty tytułowej. Dodał ponadto własnoręczne podpisy pod portretami oraz dołączył złożony na pół wycinek z gazety z widokiem centrum Petersburga i Ogrodu Letniego od strony rzeki Fontanki.

Przechodząc do omówienia polskich kalendarzy zgromadzonych przez Wolskiego warto zauważyć, że w XVIII w. dokonał się istotny zwrot w podejściu do tego typu wydawnictw. Powstał wówczas nowy rodzaj almanachu, pozbawiony części astrologicznej oraz prognostykarskiej wypełniającej dotąd obficie kalendarze staropolskie ${ }^{22}$, ale bogaty w informacje praktyczne, „dotyczące spraw bieżących, życia publicznego i działalności ważniejszych instytucji państwa"23. Otrzymał on nazwę kalendarza politycznego. Miał charakter oświeceniowy, służąc popularyzacji wiedzy wśród mniej wykształconych warstw społecznych ${ }^{24}$. Pierwszy almanach o takim profilu wydał w $1737 \mathrm{r}$. wileński jezuita Jan Poszakowski (1684-1759). Od 1752 r. drukowała je również oficyna zakonna pijarów w Warszawie, początkowo pod tytułem „Kolęda warszawska”, a następnie jako „Kalendarzyk polityczny”25.

Pijarski „Kalendarzyk polityczny na rok przybyszowy 1794” z księgozbioru Wolskiego został oprawiony w czerwony marokin. W zwierciadle obu okładek występuje superekslibris królewski Stanisława Augusta Poniatowskiego

${ }^{21}$ W. Engelmann, dz. cyt., poz. 846; W. Prajer, dz. cyt., s. 87-88.

22 Por. M. Janik, Polskie kalendarze astrologiczne epoki saskiej, Warszawa 2003, s. 6-7; tenże, Staropolski kalendarz prognostykarski jako urzadzenie komunikacyjne, [w:] Kalendarze staropolskie..., s. 125-126.

${ }^{23}$ J. Buła, Katalog kalendarzy polskich od XVI do XVIII wieku w zbiorach Biblioteki Czartoryskich, Kraków 1994, s. IX.

24 M. Gorczyńska, Popularyzacja wiedzy w polskich kalendarzach okresu Oświecenia (17371821), Lublin 1999.

25 E. Gigilewicz, H. Wąsowicz, Kalendarze polskie, [w:] Kalendarze, red. E. Gigilewicz, Lublin 2003, s. 108-109. 
ujęty ozdobną ramką (fot. 5). Na grzbiecie starodruku zastosowano dekorację ornamentalną $\mathrm{w}$ formie tłoczonych złotem waz i girland. Brzegi kart również poddano złoceniu. Pod względem formatu edycja ta jest najmniejszym almanachem w kolekcji I. Wolskiego. Na jego treść, poza właściwym kalendarium, złożyły się różnego rodzaju pomocne wykazy: od chronologii książąt i królów polskich, przez spis dygnitarzy i kawalerów Orderu Orła Białego oraz Orderu Świętego Stanisława, po szczegółowe zestawienia urzędników czy przedruk tekstów ustaw sejmowych.

Posiadanie wydawnictwa zawierającego aktualne dane statystyczne miało bez wątpienia pełnić funkcję podręcznego informatora. W czasach Wolskiego kalendarz ten nabrał już jednak znaczenia historycznego, a jego wartość podnosił dodatkowo fakt, że egzemplarz pochodził z biblioteki królewskiej. Nosi on wyraźne ślady użytkowania. Bibliofil zaznaczał i podkreślał interesujące fragmenty tekstu. Sporządzał także drobne notatki piórem, na przykład krótkie wyjaśnienie słowa „ciwun”, oznaczającego urząd ziemski w Wielkim Księstwie Litewskim, na Żmudzi i Wileńszczyźnie.

Kolejny almanach nowego typu ze spuścizny kolekcjonera pochodzi już z pierwszej połowy XIX stulecia, nie został jednak odszukany w zbiorach muzealnych. Jest to A. Gałęzowskiego i Komp. „Kalendarz domowy na rok zwyczajny 1831", skierowany głównie do właścicieli gospodarstw wiejskich, aby zaszczepić w nich ,zamiłowanie rozsądne wygód życia, oszczędności i pracowitości"26.

Bardziej naukowy charakter ma zachowany w dobrym stanie „Kalendarzyk polityczny na rok 1846", wydany w Warszawie przez Franciszka Radziszewskiego (1794-1869). Ta spora objętościowo książeczka zawiera część astronomiczno-kościelną, polityczną, statystyczno-historyczną i handlową. Ozdobiona została dwoma rycinami przedstawiającymi warszawskie zabytki: kościół św. Karola Boromeusza oraz nagrobek ostatnich książąt mazowieckich.

$\mathrm{Na}$ wyjątkowość omawianego wydawnictwa wskazuje notatka piórem umieszczona przed tekstem właściwym na karcie interfoliowanej, wykonana kaligraficznym pismem ręką I. Wolskiego (fot. 6). Warto przytoczyć ją w całości, gdyż stanowi dokument źródłowy z czasów zaborów:

Kalendarz niniejszy tem jest dla badacza naszej przeszłości ciekawy, że pomimo srogich rządów Mikołaja I, wszystkie urzędy w Królestwie Polskiem były jeszcze przez samych prawie Polaków obsadzane i że prasa była swobodniejsza; rzeczony bowiem kalendarz wydany został tylko w języku polskim, a nadto na herbie rossyjskim figuruje jeszcze Orzeł polski, co w 14 lat później, za Aleksandra IIgo, miejsca już nie miało ${ }^{27}$.

26 Przedmowa, [w:] „Kalendarz domowy na rok zwyczajny 1831”, Warszawa [1831], k. [1r.].

27 „Kalendarzyk polityczny na rok 1846”, wyd. F. Radziszewski, Warszawa [1845], k. [1r.]. Muzeum Narodowe w Krakowie, sygn. MNK VIII-kal.139. 
Wspomniany w cytacie herb wytłoczono w zwierciadle przedniej okładki kalendarza i złocono. Otacza go ślepo tłoczona bordiura przyjmująca formę dekoracji roślinnej. Natomiast w centrum tylnej okładki widnieje data roczna: „1846".

I. Wolski był patriotą i kolekcjonerem pamiątek ojczystych, troszczącym się głęboko o losy kraju zniewolonego przez politykę zaborczą. Taka postawa bibliofila ujawniła się w obszernym rękopiśmiennym komentarzu do sytuacji narodu przed powstaniem styczniowym i po jego upadku zawartym na kartach kontynuacji kalendarzyka Radziszewskiego, a mianowicie w „Roczniku urzędowym Królestwa Polskiego na rok 1863”. Liczące ponad tysiąc stron wydawnictwo, drukowane w Warszawie u Jana Jaworskiego (1815-1875), obejmuje rozbudowany spis naczelnych władz Cesarstwa oraz wszystkich władz i urzędników Królestwa Polskiego. Kolekcjoner zwraca się bezpośrednio do swoich współziomków:

Jeżeli cię, rodaku, przeszłość Twego kraju interesuje, to nie niszcz niniejszego Rocznika Urzędowego, bo z niego przekonasz się o błogich skutkach manifestacyj Polaków w r. 1861, w Warszawie i adresu ich do Cesarza Aleksandra IIgo, który uwzględniwszy zawarte w nim prośby, zamianował najprzód w r. 1861 naczelnikiem rządu cywilnego, margrabiego Wielopolskiego; w d. 26 Marca tegoż roku nadał Królestwu Polskiemu, pomiędzy innemi instytucyami rady: gubernialne, powiatowe i miejskie; w r. 1862 naznaczył na namiestnika brata swego Konstantego Mikołajewicza i rozszerzył jego atrybucje oraz udzielił następujące specyjalne dla Królestwa Polskiego prawa i reformy, pomieszczone na końcu niniejszego Rocznika $[\ldots]^{28}$.

Właściciel kalendarza wylicza następnie wprowadzone zmiany, między innymi w zakresie szkolnictwa niższego i wyższego stopnia, podkreślając jednocześnie potrzebę zachowania dla przyszłych pokoleń prezentowanego wydawnictwa jako świadectwa minionych, lepszych czasów:

Za przechowanie niniejszego Rocznika dla potomnych przemawia i to, że reformy w nim zawarte dziś (1898 r.) już wcale nie istnieją; po powstaniu bowiem 1863 r. zostały całkowicie zniesione, a w miejsce ich wprowadzony został dla Królestwa Polskiego system zupełnej rusyfikacyi, polegający na przeniesieniu wszystkich wyższych Władz Królestwa do Petersburga, - zniesieniu języka polskiego w szkołach i urzędach i zastąpieniu go rossyjskim; tudzież wydaleniu wszystkich niemal Polaków z posad rządowych i obsadzeniu ich ruskimi ${ }^{29}$.

Słowa Wolskiego, zapisane w 1898 r., zawierają też ustęp na temat reform Aleksandra Wielopolskiego (1803-1877) - naczelnika Rządu Cywilnego Królestwa Polskiego:

28 „Rocznik urzędowy Królestwa Polskiego na rok 1863”, Warszawa [1862], k. [1r.-v.]. Muzeum Narodowe w Krakowie, sygn. MNK VIII-kal.182.

29 Tamże, k. [3v.-4r.]. 
Rzeczony też Rocznik przekona Czytelnika, że za rządów Wielopolskiego, bardzo mało służyło w Królestwie Moskali, tylko sami niemal Polacy, i że cenzura była o wiele łagodniejszą, bo, jak widzimy, tenże Rocznik, już nie we dwóch językach, jak przed Wielopolskim ale w samym tylko polskim języku wydrukowany został. Obecnie, niestety, nawet i w dwóch już nie wychodzi $[\ldots]^{30}$.

Margrabia Wielopolski był postacią kontrowersyjną, zwolennikiem przeprowadzania w kraju zmian poprzez przejściową rezygnację z dążeń do odzyskania niepodległości i podporządkowanie się władzy carskiej ${ }^{31}$. Jego poglądy nie mogły zyskać aprobaty Wolskiego, który na pierwszym miejscu stawiał wolność Ojczyzny ${ }^{32}$. Bibliofil doceniał jednak szerokie korzyści płynące z możliwości swobodnego posługiwania się językiem narodowym oraz dostępności stanowisk urzędniczych dla Polaków.

Jak zauważył sam kolekcjoner, reformy polityczne znajdowały odbicie w zawartości i konstrukcji XIX-wiecznych almanachów. Omawiany rocznik, zakupiony w księgarni i składzie nut Józefa Kaufmanna ${ }^{33}$ w Warszawie (pieczątka „J. Kaufmann à Varsovie” na karcie tytułowej), jest ostatnim kalendarzem książkowym z tego stulecia zachowanym w księgozbiorze Wolskiego. Wiadomo, że posiadał on także wcześniejszą rosyjsko-polską edycję tego wydawnictwa na rok 1860, wpisaną do Inwentarza Muzeum Narodowego w Krakowie pod numerem 10122, ale nieodnalezioną przez autorkę podczas kwerendy ${ }^{34}$. Podobny, nieznany los spotkał przekazany do zbiorów muzealnych rękopis w formie kalendarium upamiętniający stulecie walki narodu polskiego o niepodległość.

$\mathrm{Z}$ początku XX w. pochodzą dwa kalendarze ludowe, realizujące nowy program społeczno-polityczny i różniące się od wcześniej opisywanych znacznie mniejszą objętością oraz większym formatem. Wydane w Warszawie na rok 1906 są sygnowane pieczątkami własnościowymi I. Wolskiego. Pierwszy, „Kalendarz polski historyczny popularny religijno-moralny”, opatrzony na

30 Tamże, k. [4v.-r.].

31 J. Śmiałowski, Zbigniew Stankiewicz: Dzieje wielkości i upadku Aleksandra Wielopolskiego. Warszawa 1967, ss. 311. [Recenzja], „Rocznik Lubelski” 1968, t. 11, s. 176-178; J. Engelgard, Aleksander Wielopolski i niepodległość Polski w latach 1861-1862, [w:] tenże, U źródeł polityki polskiej. Od Wielopolskiego do Dmowskiego, Warszawa 2018, s. 36-57.

32 W liście noworocznym, datowanym na 1905 r. i adresowanym „Do Aliny” (Muzeum Narodowe w Krakowie, sygn. MNK VIII-rkps.728/1/1), Wolski pisał: „Nie traćmy więc takowej [nadziei - przyp. A.L.] i z wiarą w lepszą przyszłość pracujmy, jak kto umie i może, dla dobra nieszczęśliwej naszej ojczyzny. A może też Bóg zlituje się nad nią i da nam oglądać jej wyzwolenie. To jest najpierwsze moje życzenie [...]".

33 Sam Kaufmann był również wydawcą kalendarzy. Por. M. Kocójowa, Kaufmann (Kaufman) Józef, [w:] PSB. T. 12, Wrocław 1966-1967, s. 233.

34 Wydawnictwo wychodziło wówczas pod zmienionym tytułem: „Rocznik urzędowy obejmujący spis naczelnych władz cesarstwa oraz spis wszelkich władz i urzędników Królestwa Polskiego na rok $1860 "$ ". 
okładce mottem „Boże zbaw Polskę” oraz wizerunkiem orła w koronie, nad którym umieszczono oko opatrzności, wyraża nadzieje niepodległościowe, rozbudzone rewolucją roku 1905 i korzystnymi zmianami zaprowadzonymi wówczas w zaborze rosyjskim ${ }^{35}$. Celem wydawnictwa, określonym już w tytule, było kształtowanie świadomości historycznej ludowego czytelnika oraz jego postawy moralnej. Nie dziwi więc zawartość almanachu. Obok właściwego kalendarium, obejmuje on kalendarz historyczny ważniejszych wypadków w kraju oraz prozę i poezję o wyraźnym zabarwieniu religijno-patriotycznym (Boże coś Polskę, Polonez Kościuszki). Uwzględniono również praktyczny aspekt publikacji, pozostawiając puste miejsce na notatki.

Odbiorca kalendarza został wyraźnie sprecyzowany w nagłówkach tekstów: Pacierz Ludu Polskiego, Gtos Boga do ludu polskiego. Wydawcy natomiast przekonywali: ,[...] własnymi siłami Polskę odbudować możemy, a kielnią naszą niech będzie jedność, a młotem wytrwałość”36. I dalej: „,...] Bóg i Religia twych ojców wzywają cię do wolności i ona jest twoim przeznaczeniem"37. Budzono tym samym ducha narodowego wśród niższych grup społecznych.

Almanachy dla ludu zyskały popularność w drugiej połowie XIX w. po uwłaszczeniu chłopów, a ich szybki rozwój wiązał się z szerzeniem w środowiskach wiejskich i robotniczych haseł pozytywizmu ${ }^{38}$. Pokupność kalendarzy na początku następnego stulecia była wciąż bardzo duża. „Zaspokajały one w jakimś stopniu potrzeby czytelnicze tych nie wyrobionych jeszcze warstw społeczeństwa, do których poza elementarzem, [...] modlitewnikiem [...] i sennikami - inna książka polska nie docierała"39. Ich lektura sprzyjała ponadto krzewieniu wiedzy, dostarczała rozrywki oraz, co istotne ze względu na trudną sytuację polityczną, poczucia przynależności do wspólnoty obywateli.

O pozytywnych skutkach wydarzeń 1905 r. w Królestwie Polskim informowała odbiorców redakcja „Przedświtu”, drugiego XX-wiecznego almanachu obecnego w kolekcji Wolskiego: „Wydając w Warszawie pierwszy po roku 1863 kalendarz polski bez cenzury prewencyjnej, nie wątpimy, iż wydawnictwo nasze odpowiada istotnym potrzebom chwili bieżącej”40. Plany

35 N. Davies, Boże igrzysko. Historia Polski. T. 2: Od roku 1795, przeł. E. Tabakowska, Kraków 1996, s. 405-407.

36 „Kalendarz polski historyczny popularny religijno-moralny na rok zwyczajny 1906”, Warszawa 1905, s. 31. Muzeum Narodowe w Krakowie, sygn. MNK Biblioteka - I 1168 s.z.

37 Tamże, s. 32.

38 E. Wójcik, dz. cyt., s. 24-26. Szerzej o kalendarzach ludowych zob.I. Turowska-Bar, Polskie kalendarze ludowe w XIX wieku, ,Rocznik Biblioteki Narodowej” 1967, z. 3, s. 241-292.

39 Kalendarz, [w:] EWOK, red. A. Birkenmajer et. al., Wrocław 1971, szp. 1091.

40 Redakcja, Od Wydawnictwa Kalendarza „Przedświt”, [w:] „Przedświt. Kalendarz polski na rok zwyczajny 1906”, Warszawa 1906, s. 3. Muzeum Narodowe w Krakowie, sygn. MNK Biblioteka - II 1449 s.z. 
redaktorów były bardzo ambitne, nie wszystkie jednak zostały zrealizowane $\mathrm{z}$ braku czasu ${ }^{41}$.

Skierowany do robotników kalendarz w secesyjnej szacie graficznej przynosi szczegółowe wiadomości na temat rewolucji w Cesarstwie Rosyjskim i na ziemiach polskich. Zarówno tytuł wydawnictwa, jak i scena alegoryczna ilustrująca okładkę (fot. 7) rozpalają wiarę w rychłe wyzwolenie spod obcego jarzma. Obszerna część literacka „Przedświtu” zawiera ustęp z dramatu Kordian Juliusza Słowackiego, Baśń o Olbrzymie, krótkie opowiadania i powiastki oraz utwory poetyckie. Zwraca uwagę dział zatytułowany Humor $i$ Satyra. Nie mogło też zabraknąć Raptularza najdonoślejszych zdarzeń z dziejów Polski. Kalendarz adresowano również do osób wyznania mojżeszowego, podając ważne dla nich święta. Mimo popularnego charakteru tego wydawnictwa ma ono oczywisty wydźwięk polityczny i jako takie zapewne znalazło się w biblioteczce I. Wolskiego.

Zainteresowania graficzne kolekcjonera zaowocowały grupą jednoplanszowych kalendarzy ściennych występujących w jego zbiorach. Niestety tylko kilka z nich dotrwało do czasów współczesnych. Są to wydawnictwa Zakładu Artystyczno-Litograficznego „Czasu” w Krakowie oraz warszawskiej firmy Maksymiliana Fajansa (1825-1890). Z obu przedsiębiorstwami związany był Henryk Walter (zm. 1860), rysownik pochodzenia francuskiego, autor znanego Albumu widoków Krakowa i jego okolic (Kraków 1860). Po przybyciu do Polski artysta pracował w zakładzie litograficznym Fajansa, a następnie, w 1858 r., przeniósł się do Krakowa, gdzie został zatrudniony przez Wincentego Kirchmayera (1820-1893), właściciela Drukarni i Litografii „Czasu”42.

Jednym z pierwszych zleceń, jakie H. Walter otrzymał od nowego pracodawcy było wykonanie kalendarza ściennego na rok 1859 (fot. 8). Ten piękny przykład zastosowania nowej barwnej techniki w litografii stanowi zarazem źródło do ikonografii XIX-wiecznego Krakowa. Kalendarium, podzielone na dwie części, zostało ujęte bogatą ramą ornamentalną ze stylizowanej wici roślinnej z wplecionymi niewielkimi postaciami kobiet i mężczyzn. W centrum, na głównej osi, znalazł się okolony wieńcem kwiatów i owoców widok domu Pod Krzysztofory, lokalu firmy Kirchmayera ${ }^{43}$. Powyżej, w zwieńczeniu, Walter umieścił kartusz z rokiem „1859”, poniżej natomiast kartusz zawierający nazwę zakładu litograficznego oraz herb Krakowa; oba flankowane grupą postaci w strojach ludowych.

Poza wiernym wyobrażeniem siedziby „Czasu” omawiany kalendarz prezentuje następujące miniaturowe widoki: Willę Decjusza na Woli Justowskiej,

41 Tamże.

42 [Nekrolog H. Waltera], „Czas” 19.06.1860, nr 138, s. 3; J. Banach, Kraków malowniczy. O albumach $z$ widokami miasta $w$ XIX wieku, Kraków 1980, s. 83-84.

43 J. Banach, dz. cyt., s. 84-86. 
ruiny zamku Tenczyn w Rudnie, kościół Mariacki wraz z jego wnętrzem, wzgórze wawelskie, Kopiec Kościuszki i kościół kamedułów na Bielanach oraz dworzec kolei żelaznej, a także wnętrze wiejskiej gospody z odbywającą się tam zabawą taneczną, będące wytworem fantazji autora. Większości przedstawień litograf nie wykonał samodzielnie z natury, ale przy wykorzystaniu wcześniejszych wzorów, między innymi albumu 24 widoków miasta Krakowa i jego okolic (Kraków 1836), wydanego przez Daniela Edwarda Friedleina (1802-1855) ze sztychami według rysunków Jana Nepomucena Głowackiego $(1802-1847)^{44}$.

W Zakładzie Artystyczno-Litograficznym „Czasu” w Krakowie ukazał się również kalendarz ścienny na rok 1861, sygnowany: „Ryt. i lit. W. Popelik”. Blankiet chromolitograficzny do tego wydawnictwa, bez nadrukowanej części kalendarzowej, posiadał I. Wolski (fot. 9). Cztery puste pola, w których miało znaleźć się kalendarium ujęto w formę architektoniczną neogotyckiego ołtarza, dekorowanego wicią roślinną i zwieńczonego obrazem Matki Boskiej Częstochowskiej. Pod nim występuje rok „1861”. Skrzydła boczne owego „ołtarza” zostały wydzielone wizerunkami świętych patronów Polski - Stanisława po lewej i Wojciecha po prawej stronie. W predelli autor umieścił pełną nazwę wydawcy otoczoną figurami świętych w arkadowych niszach. U dołu na osi głównej dodano, jak przy poprzednim kalendarzu, herb miasta. Całość blankietu, odznaczająca się żywą kolorystyką i precyzją wykonania, stanowi kolejne świadectwo udanych początków barwnej litografii krakowskiej.

W środowisku warszawskim nową technikę powielania w kolorze stosował z powodzeniem wykształcony w Paryżu M. Fajans, właściciel dużego warsztatu o aspiracjach artystycznych, stojącego zarazem na wysokim poziomie technologicznym ${ }^{45}$. Jego kalendarz chromolitograficzny na rok 1860, będący wynikiem współpracy z malarzem Józefem Simmlerem (1823-1868), ukazuje pośrodku scenę rodzajową (fot. 10). Pod rozłożystym drzewem siedzi starszy mężczyzna ubrany w strój szlachecki z mieczem w lewej dłoni. O jego ramię wspiera się młoda kobieta w czarnej sukni przewiązanej sznurem. Obie postaci mają zatroskane, zadumane oblicza. Przedstawieniu towarzyszy czterowiersz zaczerpnięty z Marii Antoniego Malczewskiego (1793-1826):

Pod staremi lipami Miecznik dumał stary,

I dźwigał w zwiędłej głowie utrapień ciężary.

Przy nim młoda niewiasta - czemuż, kiedy młoda,

Tak zamglonym promieniem świeci jej uroda?

44 Tamże, s. 28-34, 86.

45 I. Tessaro-Kosimowa, Historia litografii warszawskiej, Warszawa 1973, s. 62, 239; D. Jackiewicz, Maksymilian Fajans 1825-1890, Warszawa 2014, s. 6-10. 
Scenka, ujęta ramą architektoniczno-rzeźbiarską, w którą w dwóch szpaltach wpisano część kalendarzową, stanowi zatem ilustrację pierwszej polskiej powieści poetyckiej wydanej w $1825 \mathrm{r}$. J. Simmler pracował nad cyklem sześciu szkiców do tego utworu podczas pobytu za granicą, jednak tylko dwa rysunki przybrały formę obrazów olejnych - popularne Pożegnanie Wacława $z$ Maria (1848) oraz zaginiony Maria i Miecznik (1849) ${ }^{46}$. W kalendarzu Fajansa znalazła się litograficzna reprodukcja ostatniego tytułu: sentymentalne spotkanie ojca i córki przeczuwających przyszłe smutne wydarzenia. Wykorzystanie dzieła znanego artysty było zabiegiem celowym. Tragiczne losy bohaterów utworu Malczewskiego, nawiązującego do twórców gatunku powieści poetyckiej Waltera Scotta (1771-1832) i George'a Gordona Byrona (1788-1824), można bowiem interpretować w kontekście niepewnej sytuacji Polaków przed wybuchem powstania styczniowego ${ }^{47}$. Postawa Miecznika, będącego uosobieniem prawdziwego patrioty, musiała też wzbudzić sympatię I. Wolskiego, który pieczołowicie przechował omawiany kalendarz w swoich zbiorach.

Na zakończenie warto poświęcić kilka słów nieodnalezionym kalendarzom ściennym z kolekcji muzealnego darczyńcy. Są to kalendarze fotograficzne na lata 1866 (fot. 11), 1867, 1868 oraz 1869 wykonane w warszawskim Zakładzie K. Brandla i Spółki. Jak pisała Krystyna Lejko, należą one „do najbardziej oryginalnych, a zarazem szczególnie interesujących źródeł ikonograficznych ukazujących Warszawę - jej zabudowę, życie kulturalne i znane osobistości [...] z lat 60. XIX wieku"48. Zastosowanie nowej techniki przy produkcji plansz, polegające na zastąpieniu dotychczasowej litografii fotografią, a właściwie fotomontażem, spotkało się z przychylnym przyjęciem publiczności. Pojawienie się w sprzedaży pierwszego kalendarza uznano wręcz za „wydarzenie towarzyskie" 49 .

K. Brandel (1838-1920) jako uczeń Karola Beyera (1818-1877) oraz autor zdjęć stolicy wykonywanych podczas lotu balonem w 1865 r. miał jeszcze przed otwarciem własnego atelier spore doświadczenie w tej dziedzinie. Był też wynalazcą przenośnego aparatu fotograficznego, zwanego „fotorewolwerem". Zbliżonymi kompetencjami mógł pochwalić się również współwłaściciel firmy - Marcin Olszyński (1829-1904) - fotograf, kierownik artystyczny

46 R. Biernacka, Simmler Jakub Józef (1823-1868), [w:] PSB, Warszawa-Kraków 1996-1997, t. 37, s. 512; Józef Simmler 1823-1868. Polenmuseum Rapperswil, 26. Juni-15. August 1993. Ausstellungskatalog, bearb. von E. Charazińska, Warszawa 1993, s. 45, 53, 77.

47 A. Witkowska, R. Przybylski, Romantyzm, Warszawa 1997, s. 212, 218.

48 K. Lejko, Kalendarze fotograficzne z zaktadu Konrada Brandla. Obraz życia Warszawy w latach 60. XIX wieku, Warszawa 2009, s. 5. Lejko dotarła do niewielu zachowanych przykładów tego wydawnictwa, a kalendarz z 1867 r. omówiła wyłącznie na podstawie reprodukcji zamieszczonej w następnym roczniku. Z głównego Inwentarza Muzeum Narodowego w Krakowie wynika, że I. Wolski posiadał wszystkie cztery plansze: nr 10192-10195.

49 Tamże, s. 12-14. 
czasopisma „Kłosy”50. Z zakładem współpracowali ponadto artyści: Wojciech Gerson (1831-1901) oraz Henryk Pillati (1832-1894), który wspomniane wydawnictwa z lat 1868 i 1869 wzbogacił o elementy satyryczne ${ }^{51}$.

Mieszkający na stałe w dawnej stolicy Wolski musiał interesować się bieżącymi sprawami, a ścienne kalendarze K. Brandla i Spółki stanowiły swoistą kronikę życia tego miasta. Nic dziwnego, że znalazły się w posiadaniu zbieracza.

Czytelnicze wybory I. Wolskiego i zgromadzony przez niego księgozbiór sytuują warszawskiego kolekcjonera w kręgu bibliofilów-patriotów, osób żywo zaniepokojonych trudną sytuacją narodu pod zaborami, starających się ratować wszelkie przejawy polskości ${ }^{52}$. Podobnie omawiane w artykule kalendarze daty ich wydania, związane z ważnymi dla kraju wydarzeniami $(1794,1831$, 1846,1863 ) oraz pozostawione na interfoliowanych kartach notatki - ujawniają, że obecność tych obiektów w biblioteczce Wolskiego nie była przypadkowa. Stanowiły one świadectwo przeszłości, pamiątki ojczyste, a także źródło kulturowo-historyczne. Potrzeba zachowania ich dla przyszłych pokoleń, potwierdzona przekazaniem zbioru do Muzeum Narodowego w Krakowie, wydaje się istotnym motywem gromadzenia.

Almanachy ozdobione pięknymi rycinami, kalendarze ścienne litografowane lub fotograficzne zaspokajały ponadto artystyczne upodobania kolekcjonera. Na potwierdzenie tej tezy można wskazać teczkę Wolskiego, przechowywaną w Gabinecie Grafiki i Rysunku MNK, zatytułowaną przez donatora Album portretów wyjętych $z$, Kalendarza Ungra” (sygn. MNK III-ryc.62361) ${ }^{53}$. Zawiera ona życiorysy i wizerunki znakomitych ludzi, drukowane w wydawnictwie Józefa Ungra (1817-1874) na przestrzeni lat 1872-1898. Otwartą pozostaje jednak kwestia, czy ofiarodawca zbierał poszczególne roczniki tej publikacji, pozostawiając jedynie część poświęconą znanym osobistościom, czy też wszedł w posiadanie owych fragmentów w inny sposób.

50 W. Żdżarski, Historia fotografii warszawskiej, Warszawa 1974, s. 49-51, 105-111; D. Jackiewicz, Konrad Brandel 1838-1920, Warszawa 2015, s. 8-11, 24-25.

$51 \quad$ K. Lejko, dz. cyt., s. 68, 72.

52 A. Lubera, Dary biblioteczne...

${ }_{53}$ Za wskazanie albumu dziękuję pani Dominice Bartik-Osikowicz pracującej w Gabinecie Grafiki i Rysunku MNK. 
Katalog kalendarzy z kolekcji Ignacego Wolskiego zachowanych w zbiorach Muzeum Narodowego w Krakowie

Kalendarze książkowe - XVIII w.

Königl. Grosbritannischer Historischer Genealogischer Calender für 1792 mit Kupfern von Chodowiecki in gemeinschaftlichem Verlag von Berenberg in Lauenburg und der Jägerische Buchhandlung in Frankfurth a/m. Lauenburg : Verlag von Berenberg; Frankfurt am Main : Jägerische Buchhandlung, [1791]. [30], VIII, 205, [3] s., [20] k. tabl.; sygn. A-P8 ; format $24^{\circ}$.

Zawiera: Zeitrechnung. Zeichen der Planeten. Quatember. Vier Jahrszeiten. Sonnen- und Mondfinsternisse. Allgemeiner Reichs-Kalender. Rußischer Kalender. Auf- und Untergang der Sonne und des Mondes. Mondwandlung. Erscheinung der Planeten. Erklärung der Monatskupfer. Geburtstage des hohen Königl. und Churfürstlichen Hauses. Genealogisches Verzeichniß der vornehmsten jetztlebenden Fürstl. Personen in Europa. Geschichte der Wenden. Vom Ursprung der Kutschen. Beschreibung der weißen Mohren. Naturgeschichte des Löwen. Vom Gebrauch der Taschenuhren. Von der prachtvollen Ceremonie der Vermählung des Doge von Venedig mit dem Adriatischen Meere. Ueber die Zärtlichkeit. Etwas über Titulaturen. Geschichte des Brannteweins. Geburts- Sterbe- und Ehe-Listen der vornehmsten Städte in Europa, vom Jahre 1790. Von den Zügen der Heringe. Beitrag zur Geschichte der Moden. Gewissensfragen an das Freuenzimmer. Vergleichung der gebräuchlichsten Thermometer. Vorstellung des Sonnensystems. Meilenzeiger für die Königl. deutschen Lande. Allgemeiner Meilenzeiger. Vergleichung der Messen. Lauf der Posten von Hannover. Verzeichniß einiger berühmten Messen und Jahrmärkte. Nachricht.

Ilustracje: frontisp., sygn.: D. Chodowiecki del. (Daniel Chodowiecki, 17261801), F.L. Neubauer Sculp: am Francfort (Friedrich Ludwig Neubauer, 17671828); [6] k. tabl. poświęconych modzie, sygn.: P.W. Schwarz direx. Nbg. 1791 (Paul Wolfgang Schwarz); [12] k. tabl. z cyklu „taniec śmierci”, sygn.: D. Chodowiecki inv: \& sc: 1791.

Oprawa: pergamin; tłoczenie złotem: w zwierciadle obu okł. kwiat, wąska bordiura; obcięcia k. złocone.

Egz. z notatkami I. Wolskiego. Dod. k. tyt. druk. w jęz. pol. - koniec XIX w. Stan zachowania: średni; zniszcz.: zabrudzenia na oprawie, okł. część. oderwana, część. luźny skład.

Znaki proweniencyjne: naklejka w lewym dolnym rogu przedniej wyklejki 
- „No. 18. Ze zbiorów Ign. Wolskiego DAR TEGOŻ dla Muzeum Narodowego w Krakowie 1898 r.”

Inwentarz MNK: nr 10119, dar 1898 r.

Sygn. MNK VIII-kal.46

Kalendarzyk polityczny na rok przybyszowy 1794 . W Warszawie : w Drukarni J.K.Mci i Rzplitej u XX Scholarum Piarum, [1793]. (Zakończono drukować d. 20 listop. 1793). [160] k., sygn.: A-N12 O4 ; format $12^{\circ}$.

Zawiera: [Kalendarium]. Chronologia książąt i królów polskich. Imiona panów europejskich i ich familii. [Dygnitarze kościelni i świeccy w Polsce]. Kawalerowie Orderu Orła Białego. Kawalerowie Orderu Ś. Stanisława. Kawalerowie Maltańscy w Polszcze. Kawalerowie zaszczyceni Krzyżem Devotionis. Damy Krzyżem Orderowym zaszczycone. Urzędnicy ziemscy i grodzcy w Koronie i W. Ks. Lit. Magistratury i jurysdykcje sądowe. Zbiór ustaw Sejmu Ekstraordynaryjnego Grodzieńskiego r. 1793. Doniesienie po wydrukowaniu. Odmiany po wydrukowaniu.

Ilustracje drzewor.: herb Stanisława Augusta Poniatowskiego na k. tyt.

Oprawa: czerwony marokin; tłoczenie złotem: superekslibris królewski Stanisława Augusta Poniatowskiego w zwierciadle obu okł., wokół wąska bordiura, na grzb. dekoracja w formie waz i girland; obcięcia k. złocone.

Egz. z notatkami I. Wolskiego.

Stan zachowania: dobry; zniszcz.: delikatne wytarcia na oprawie, niektóre k. uszkodzone, drobne plamy.

Znaki proweniencyjne: naklejka w lewym dolnym rogu przedniej wyklejki „No. 2. Ze zbiorów Ign. Wolskiego DAR TEGOŻ dla Muzeum Narodowego w Krakowie 1898 r."

Inwentarz MNK: nr 10120, dar 1898 r.

Sygn. MNK VIII-kal.257

Almanach historique et généalogique pour l'année commune 1798. Contenant un essai historique de la vie de Catherine II. Orné de portraits, de vues, de médailles et de 8 estampes, dont les sujets sont pris du règne de Catherine. Berlin : chez Jean Fréderic Unger, [1797]. [20], 130, [160] s., [25] k. tabl.; sygn. A-A12 a-e12 f1-5 B-G12 H1-8; format $24^{\circ}$.

Zawiera: L'année 1798. Echéance des Appointemens et des Pensions. Les Éclipses. [Le calendrier]. Table du lever, du coucher et des autres positions de la Lune. Tems du lever et du coucher du Soleil. Equation de l'horloge. Catherine II. ou essai historique de sa vie en neuf tableaux. Anecdotes, tirées de la vie des 
grands hommes qui se sont distingués sous le règne de Catherine. Naissances et alliances des rois, reines, princes et princesses de l'Europe. Tableau du départ et de l'arrivée des postes dans les principales villes des états qrussiens. Table alphabétique des lieux indiqués dans le Tableau du cours des postes. Liste des plus célébres foires avec l'indication des jours qu'elles se trendront. Ilustracje: alegoria rządów Katarzyny II, sygn. J. W. Meil inv. et sc.; [8] k. tabl. poświęconych życiu Katarzyny II, sygn. D. Chodowiecki del. 1797 (Daniel Chodowiecki, 1726-1801); [14] k. tabl. z portretami i medalami, sygn. Meno Haas, Meno Haas Sc:, M:Haas Sc: (Johann Meno Haas, 1752-1833), sygn. W. Arndt Sc: (Wilhelm Arndt, 1750-1813).

Oprawa: papier, tektura; tłoczenie ślepe: wąska bordiura; obcięcia k. złocone; XIX w.

Egz. z notatkami I. Wolskiego. Dod. k. tyt. druk. w jęz. pol. - XIX w.

Stan zachowania: dobry; zniszcz.: delikatne otarcia na okł., plamy na tabl.

Znaki proweniencyjne: naklejka w lewym dolnym rogu przedniej wyklejki „No. 17. Ze zbiorów Ign. Wolskiego DAR TEGOŻ dla Muzeum Narodowego w Krakowie 1898 r.”

Inwentarz MNK: nr 48734, dar 1898 r.

Sygn. MNK VIII-kal.64

Kalendarze książkowe - XIX w.

Kalendarzyk polityczny na rok 1846 / wydany przez Fr. Radziszewskiego. Rok czternasty. W Warszawie : w Drukarni przy ulicy Bednarskiej No 2673 lit. a., [1845]. (Zakończono drukować d. 20 Grudnia 1845 r.). [8], 522, 56 s., [2] k. tabl., [1] k. interfol. ; $13 \mathrm{~cm}$.

Zawiera: Zmiany zaszłe w czasie druku i uzupełnienia. Część astronomicznokościelna: kalendarz świąt, lunacji i zaćmień na rok 1846, dnie galowe dworskie. Część polityczna: objaśnienie skróceń, Dom Cesarski Rosyjski, genealogia monarchów i książąt panujących, epoki objęcia rządów przez monarchów i książąt panujących, poczet monarchów i książąt panujących podług starszeństwa ich wieku, Cesarstwo Rosyjskie [spis naczelnych władz], Królestwo Polskie (władze naczelne, kom. rządowe, ich wydziały i N. Izba Obrach., władze i instyt. niezależ. od kom. rząd., władze miejscowe). Część druga: statuta Orderów S. Włodzimierza i S. Anny, grobowiec ostatnich książąt mazowieckich, trakty pocztowe w Królestwie Polskiem, odległość znaczniejszych miast w Europie od Warszawy, tabela odchodu i przychodu poczt w Warsz. 
Ilustracje litogr.: kościół Ś. Karola Boromeusza w Warszawie, grobowiec ostatnich książąt mazowieckich w kościele katedralnym Sgo Jana w Warszawie. Oprawa: płótno, tektura; tłoczenie złotem: tyt. i rok na grzb., herb Królestwa Polskiego na przedniej okł., rok „1846” na tylnej okł.; tłoczenie ślepe: bordiura roślinna na obu okł.; obcięcia k. złocone.

Egz. interfol. z notatkami I. Wolskiego.

Stan zachowania: dobry; zniszcz.: drobne plamy i zabrudzenia.

Znaki proweniencyjne: naklejka w lewym dolnym rogu przedniej wyklejki „No. 3. Ze zbiorów Ign. Wolskiego DAR TEGOŻ dla Muzeum Narodowego w Krakowie 1898 r."; piecz. owalna z herbem Królestwa Polskiego na k. tyt.: „, 7 1/2 Копъекъ Kopiejek 7 1/2”.

Inwentarz MNK: nr 10123, dar 1898 r.

Sygn. MNK VIII-kal.139

Rocznik urzędowy Królestwa Polskiego na rok 1863. Warszawa : w Drukarni J. Jaworskiego, [1862]. [16], 676, 362, CLIX s., [2] k. tabl. złoż., [26] k. interfol. ; $12 \mathrm{~cm}$.

Zawiera: Objaśnienia skróceń. Kalendarz na rok 1863. [Spis naczelnych władz Cesarstwa Rosyjskiego oraz wszystkich władz i urzędników Królestwa Polskiego]. Dodatek: genealogia monarchów i książąt panujących zagranicznych, ważniejsze postanowienia rządowe wydane w ciągu roku 1862, wykonanie praw o radach miejskich i powiatowych, tablica obejmująca wyrachowanie tymczasowego okupu prawnego za robociznę odbywaną przez włościan pańszczyźnianych, osiedlonych w dobrach prywatnych i instytutowych, budżet ogólny dochodów i wydatków Królestwa Polskiego na rok 1863. Skorowidz.

Ilustracje: wizerunki herbów poszczególnych guberni: warszawskiej, radomskiej, lubelskiej, augustowskiej, płockiej.

Oprawa: półskórek; tłoczenie złotem: tyt. i rok na grzb.

Egz. interfol. z notatkami I. Wolskiego.

Stan zachowania: średni; zniszcz.: otarcia skóry na grzb., przednia okł. częśc. oderwana, plamy na $\mathrm{k}$.

Znaki proweniencyjne: naklejka w lewym dolnym rogu przedniej wyklejki „No. 5. Ze zbiorów Ign. Wolskiego DAR TEGOŻ dla Muzeum Narodowego w Krakowie 1898 r.”; pieczątka owalna u dołu k. tyt.: ,J. Kaufmann à Varsovie”. Inwentarz MNK: nr 10124, dar 1898 r.

Sygn. MNK VIII-kal.182 
Kalendarze książkowe - XX w.

Kalendarz polski historyczny popularny religijno-moralny na rok zwyczajny 1906. Warszawa : [b.w.], 1905. 42, [6] s. ; $19 \mathrm{~cm}$.

Zawiera: Modlitwa. [Kalendarium]. Kalendarz historyczny ważniejszych wypadków w Polsce. Pacierz Ludu Polskiego. Głos Boga do ludu polskiego / przez Fijałkowskiego. Boże coś Polskę / Alojzy Feliński. Polonez Kościuszki. Bartosz. Notatnik.

Oprawa: papier.

Stan zachowania: dobry.

Znaki proweniencyjne: piecz. tuszowa na odwrocie przedniej okł. w lewym górnym rogu - „Muzeum Narodowe z daru Ignacego Wolskiego”.

Numery dawne: X Ws 1724, Spis z nat.: 713/371.

Dar 1906 r.

Sygn. MNK Biblioteka - I 1168 s.z.

Przedświt. Kalendarz polski na rok zwyczajny 1906. Warszawa : [b.w.], 1906. 63, [1] s. : il. ; $22 \mathrm{~cm}$.

Zawiera: Od Wydawnictwa Kalendarza „Przedświt” / Redakcja. [Kalendarium]. Święta wyznania Mojżeszowego. Dni nieprotestowe. Raptularz najdonoślejszych zdarzeń z dziejów Polski. Kronika najdonoślejszych wydarzeń z roku 1905 w Królestwie Polskiem i w Cesarstwie Rosyjskiem. Tym którzy padli / St. P. Na przełomie / L. Ch. Ustęp z poematu Juliusza Słowackiego Kordian. Baśń o Olbrzymie / Pst. Wióry / Stefan Kiedrzyński. Za naszych czasów / St. P-j. [Wiersz] / Jan Kasprowicz. 30-ci godzin w areszcie policyjnym (opowiadanie robotnika) / J. Duchiński. Humor i Satyra.

Oprawa: karton.

Stan zachowania: dobry.

Znaki proweniencyjne: piecz. tuszowa na odwrocie przedniej okł. w lewym górnym rogu - „Muzeum Narodowe z daru Ignacego Wolskiego”.

Numery dawne: X 12109, Spis z nat.: 731/883.

Dar 1906 r.

Sygn. MNK Biblioteka - II 1449 s.z. 
Kalendarze jednoplanszowe ścienne

Kalendarz ścienny na rok 1859.

Autor: Henryk Walter (zm. 1860), Zakład Artystyczno-Litograficzny „Czasu”.

Miejsce powstania: Kraków.

Czas powstania: $1858 \mathrm{r}$.

Technika: chromolitogr.

Materiał: karton.

Wymiary: wys. $46 \mathrm{~cm}$, szer. $59 \mathrm{~cm}$.

Układ: poziomy.

Znaki twórcy/wytwórni: Ułożył i litogr. H. Walter, / w Litografii „Czasu”; ZAKŁAD / Artystyczno-Litograficzny / „CZASU” / W KRAKOWIE.

Zawiera widoki Krakowa: Dom Pod Krzysztofory na Rynku Głównym, Willa Decjusza na Woli Justowskiej, zamek Tenczyn w Rudnie, kościół Mariacki, Zamek Królewski na Wawelu, Kopiec Kościuszki i kościół kamedułów na Bielanach, dworzec kolei żelaznej.

$\mathrm{Na}$ odwrocie notatka I. Wolskiego: „Kalendarz chromolitograficzny z roku 1859-go wykonany w zakładzie Artystyczno-litograficznym »Czasu« w Krakowie".

Stan zachowania: dobry.

Inwentarz MNK: nr 8696, dar 1896 r.

Sygn. MNK III-ryc.20413

Kalendarz ścienny na rok 1860.

Autor: Maksymilian Fajans (1825-1890), Zakład Artystyczno-Litograficzny Maksymiliana Fajansa.

Miejsce powstania: Warszawa.

Czas powstania: $1859 \mathrm{r}$.

Technika: chromolitogr.

Materiał: karton.

Wymiary: wys. $32 \mathrm{~cm}$, szer. $43,5 \mathrm{~cm}$.

Układ: poziomy.

Znaki twórcy/wytwórni: Podług Obrazu J. Simmlera; ZAKŁAD ARTYSTYCZNO- LITOGRAFICZNY / M. FAJANSA / w Warszawie Ulica Długa No. 550; Nakład i Własność M. Fajansa.

Zawiera reprodukcję obrazu Józefa Simmlera (1823-1868) Maria i Miecznik oraz fragment powieści poetyckiej Maria Antoniego Malczewskiego (1793-1826).

Na odwrocie notatka I. Wolskiego: „Kalendarz Chromolitograficzny z 1860 r. wykonany w zakładzie litograficznym Maksymiliana Fajansa w Warszawie”. 
Stan zachowania: dobry; uszkodzenie w prawym górnym rogu. Inwentarz MNK: nr 10190, dar 1898 r.

Sygn. MNK III-ryc.20424

Blankiet na kalendarz ścienny na rok 1861.

Autor: W. Popelik, Zakład Artystyczno-Litograficzny „Czasu”.

Miejsce powstania: Kraków.

Czas powstania: $1860 \mathrm{r}$.

Technika: chromolitogr.

Materiat: karton.

Wymiary: wys. $33,5 \mathrm{~cm}$, szer. $50,6 \mathrm{~cm}$.

Układ: poziomy.

Znaki twórcy/wytwórni: niesygn.; ZAKŁAD / Artystyczno-Litograficzny / „CZASU”/ w Krakowie.

Stan zachowania: dobry.

Inwentarz MNK: nr 10191, dar 1898 r.

Sygn. MNK III-ryc.22881

\section{Bibliografia}

Banach J., Kraków malowniczy. O albumach z widokami miasta $w$ XIX wieku, Kraków 1980.

Biernacka R., Simmler Jakub Józef (1823-1868), [w:] PSB. T.37, Warszawa-Kraków 1996-1997, s. 511-515.

Buła J., Katalog kalendarzy polskich od XVI do XVIII wieku w zbiorach Biblioteki Czartoryskich, Kraków 1994.

Chojnacki W., Chojnacki W., Bibliografia kalendarzy polonijnych 1838-1982, Wrocław 1984.

Chojnacki W., Chojnacki W., Bibliografia kalendarzy wydanych w języku polskim poza granicami Polski od roku 1716 (Mazury, Śląsk Górny i Dolny oraz Ślask Cieszyński), Wrocław 1986.

Davies N., Boże igrzysko. Historia Polski. T. 2: Od roku 1795, Kraków 1996.

Dunikowska I., Grafika Daniela Chodowieckiego w zbiorach Muzeum-Zamku w Lańcucie. Katalog wystawy, Łańcut 1972.

Engelgard J., Aleksander Wielopolski i niepodległość Polski w latach 1861-1862, [w:] tenże, Uźródeł polityki polskiej. Od Wielopolskiego do Dmowskiego, Warszawa 2018, s. 36-57. 
Engelmann W., Daniel Chodowiecki's sämmtliche Kupferstiche. Beschrieben, mit historischen, literarischen und bibliographischen Nachweisungen, der Lebensbeschreibung des Künstlers und Registern versehen, Leipzig 1857.

Gigilewicz E., Wąsowicz H., Kalendarze polskie, [w:] Kalendarze, red. E. Gigilewicz, Lublin 2003, s. 107-117.

Gloger Z., Kalendarz, [w:] tenże, Encyklopedia staropolska ilustrowana. T. 2, Warszawa 1901, s. 306-316.

Gorczyńska M., Popularyzacja wiedzy w polskich kalendarzach okresu Oświecenia (17371821), Lublin 1999.

Górska B., Katalog kalendarzy XVII-XVIII w. w zbiorach Biblioteki Ossolińskich, Wrocław 1968.

Iversen Û.B., Medali v čest russkih gosudarstvennyh deâtelej i častnyh lic. T. 1. Sanktpeterburg 1880.

Jackiewicz D., Konrad Brandel 1838-1920, Warszawa 2015.

Jackiewicz D., Maksymilian Fajans 1825-1890, Warszawa 2014.

Janik M., Polskie kalendarze astrologiczne epoki saskiej, Warszawa 2003.

Janik M., Staropolski kalendarz prognostykarski jako urzadzenie komunikacyjne, [w:] Kalendarze staropolskie, red. I.M. Dacka-Górzyńska, J. Partyka, Warszawa 2013, s. 117-153.

Józef Simmler 1823-1868. Polenmuseum Rapperswil, 26. Juni-15. August 1993. Ausstellungskatalog, bearb. von E. Charazińska, Warszawa 1993.

Kalendarz, [w:] EWOK, red. A. Birkenmajer et. al., Wrocław 1971, szp. 1087-1092.

Kłodzińska K., Katalog kalendarzy od XVI do XVIII w. w zbiorach Biblioteki Kórnickiej, „Pamiętnik Biblioteki Kórnickiej” 1963, z. 8, s. 176-297.

Kocójowa M., Kaufmann (Kaufman) Józef, [w:] PSB, Wrocław 1966-1967, s. 233.

Kosior K., Matyjasek D., ,Zegar bije - czas ucieka...” Z dziejów zegara i polskiego kalendarza. Wystawa w Muzeum Podlaskim w Białymstoku, październik-grudzień 2008, Białystok 2008.

Krzysztofik M., Kategoria czasu antropologicznego w polskim kalendarzu XVII-wiecznym, [w:] Kalendarze staropolskie, red. I.M. Dacka-Górzyńska, J. Partyka, Warszawa 2013, s. 79-86.

Lejko K., Kalendarze fotograficzne z zakładu Konrada Brandla. Obraz życia Warszawy w latach 60. XIX wieku, Warszawa 2009.

Lubera A., Dary biblioteczne Ignacego Wolskiego dla Muzeum Narodowego w Krakowie, [w:] Książka i biblioteki na przestrzeni wieków. Materiały z konferencji naukowej, Katowice, 23 maja 2018 r. (w przygotowaniu).

Lubera A., Ignacy Wolski - zapomniany darczyńca Muzeum Narodowego w Krakowie, „Rozprawy Muzeum Narodowego w Krakowie” 2018, t. 12, s. 170-178.

[Nekrolog H. Waltera], „Czas”, 19.06.1860, nr 138, s. 3.

Rok B., Kalendarz, [w:] Encyklopedia książi. T. 2: K-Z, red. A. Żbikowska-Migoń, M. Skalska-Zlat, Wrocław 2017, s. 21-25. 
Paterak M., Stare kalendarze i almanachy w zbiorach Biblioteki Muzeum-Zamku w Lańcucie. Katalog, Łańcut 1978.

Prajer W., Katalog rycin Daniela Chodowieckiego znajdujących się w Muzeum Narodowym w Krakowie, Kraków 1902.

Śmiałowski J., Zbigniew Stankiewicz: Dzieje wielkości i upadku Aleksandra Wielopolskiego. Warszawa 1967, ss. 311. [Recenzja], „Rocznik Lubelski” 1968, t. 11, s. 175-179.

Tessaro-Kosimowa I., Historia litografii warszawskiej, Warszawa 1973.

Turowska-Bar I., Polskie kalendarze ludowe w XIX wieku, „Rocznik Biblioteki Narodowej" 1967, z. 3, s. 241-292.

Witkowska A., Przybylski R., Romantyzm, Warszawa 1997.

Wójcik E., Kalendarze dwudziestolecia międzywojennego (dzieje, problemy literatury i kultury, bibliografia), Kraków 2000.

Zabuska K., Daniela Chodowieckiego przypadki. Rzecz o artyście spetnionym z Gdańskiem i Berlinem w tle, Gdańsk 2018.

Zabuska K., Zbiory Muzeum Narodowego w Gdańsku. Kolekcja Jacoba Kabruna. Ryciny szkoty niemieckiej od końca XV do początku XIX wieku. Cz. 2: Ryciny Daniela Chodowieckiego, Gdańsk 2015.

Żdżarski W., Historia fotografii warszawskiej, Warszawa 1974. 
Fot. 1. „Königl. grosbritannischer historischer genealogischer Calender für 1792”, Lauenburg : Verlag von Berenberg ; Frankfurt am Main : Jägerische Buchhandlung, [1791], oryginalna karta tytułowa. Źródło: Muzeum Narodowe w Krakowie, sygn. MNK VIII-kal.46. Zdjęcie: Pracownia Fotograficzna MNK

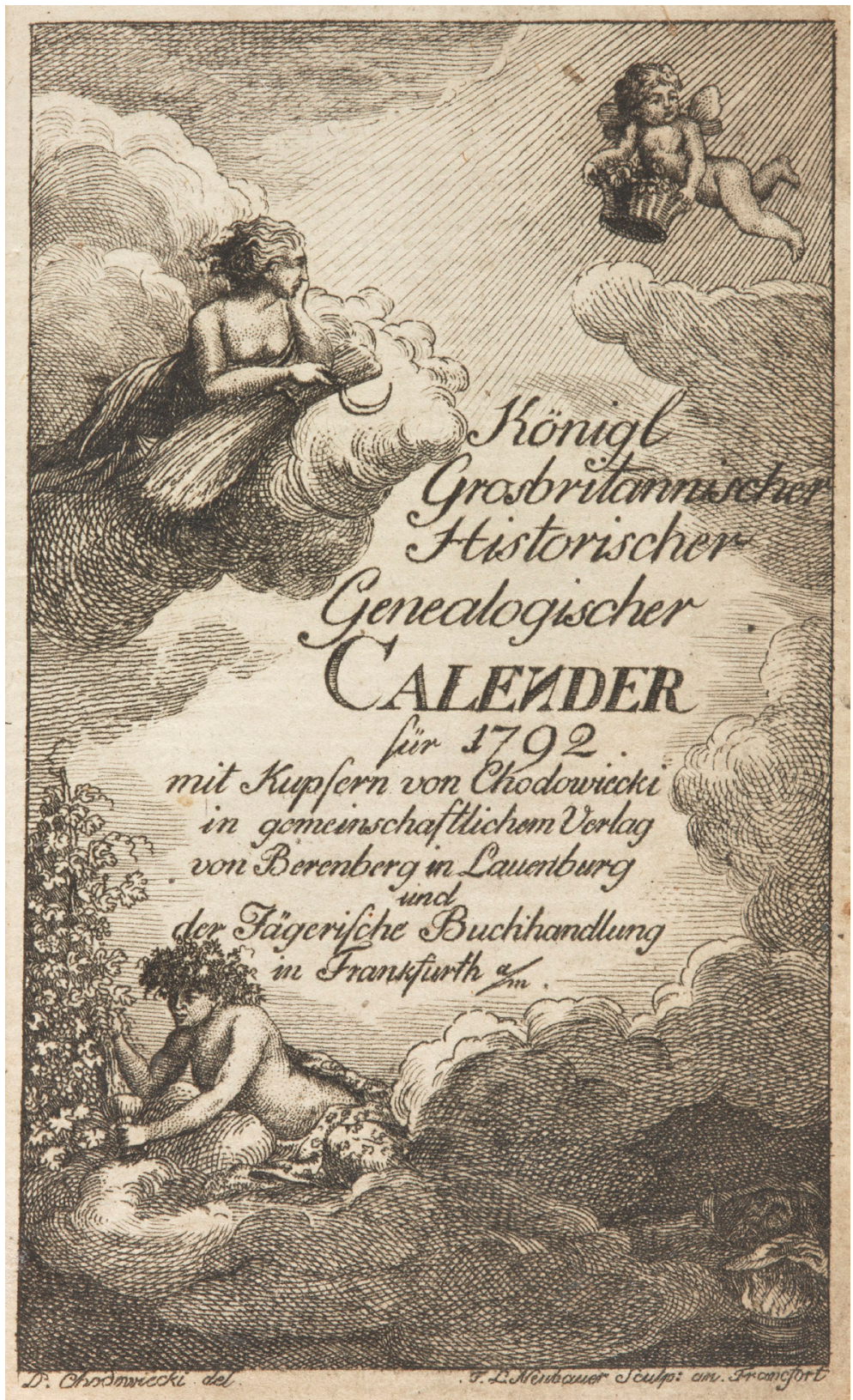


Fot. 2. „Königl. grosbritannischer historischer genealogischer Calender für 1792”, Lauenburg : Verlag von Berenberg ; Frankfurt am Main : Jägerische Buchhandlung, [1791], karta tytułowa w języku polskim wykonana na zlecenie I. Wolskiego. Zródło: Muzeum Narodowe w Krakowie, sygn. MNK VIII-kal.46. Zdjęcie: Pracownia Fotograficzna MNK

\section{KRÓLEWSKO- WIELKO - BRYTAŃSKI,}

Historyezno - Genealogiczny RALEDDARE, na Rok 1792 ,

? rysunkaml najnowszych ówcezesnych mód i miedsiorytami

CMODOWIEGKIEGO, przedstawiającemi śmierć, wszystkie stany 1นdzI zàblerającą.

WSPÓLNE WYDANIE BERERNBERGA w Lauenburgi i KSIĘGARNI JAEGERA we Frankfurcie nad Menem. 
Fot. 3. D. Chodowiecki, Die Mutter, [w:] „Königl. grosbritannischer historischer genealogischer Calender für 1792", Lauenburg : Verlag von Berenberg ; Frankfurt am Main : Jägerische Buchhandlung, [1791]. Źródło: Muzeum Narodowe w Krakowie, sygn. MNK VIII-kal.46. Zdjęcie: Pracownia Fotograficzna MNK

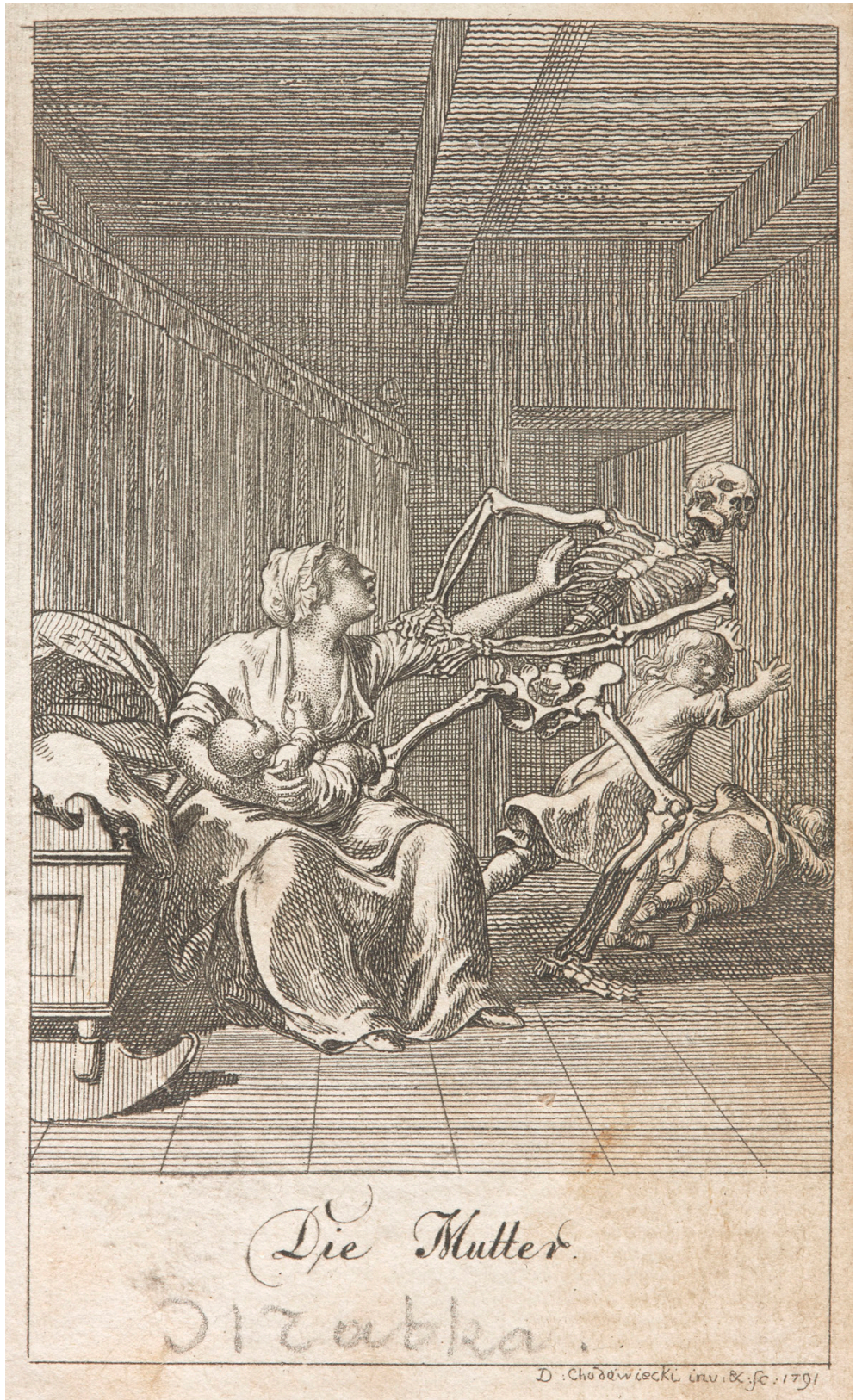


Fot. 4. D. Chodowiecki, Scena z przyjęcia u Potiomkina, [w:] „Almanach historique et généalogique pour l'année commune 1798", Berlin : chez Jean Frédéric Unger, [1797]. Źródło: Muzeum Narodowe w Krakowie, sygn. MNK VIII-kal.64. Zdjęcie: Pracownia Fotograficzna MNK

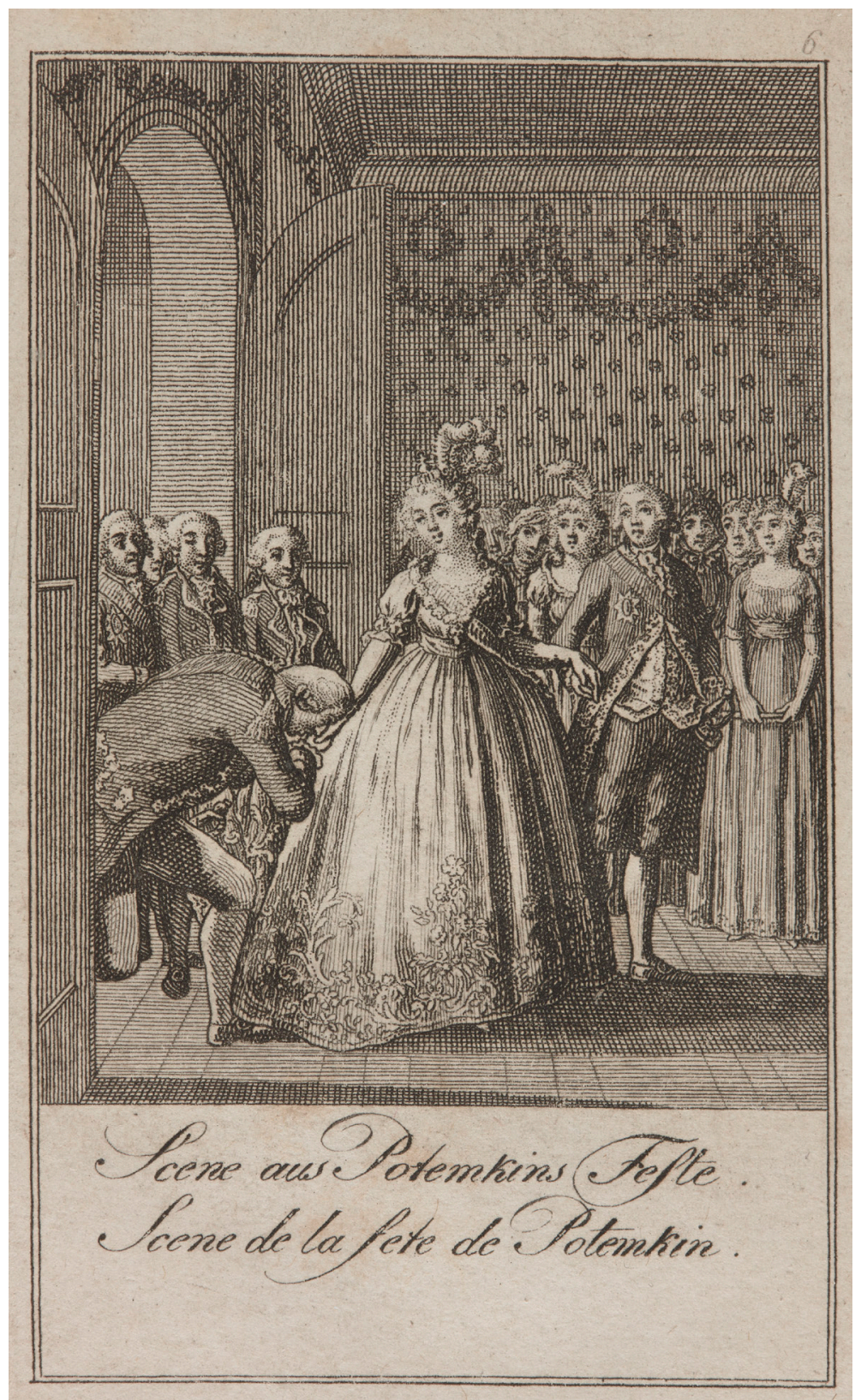


Fot. 5. „Kalendarzyk polityczny na rok przybyszowy 1794”, Warszawa : Druk. J.K.Mci i Rzplitej u XX Scholarum Piarum, [1793], oprawa. Źródło: Muzeum Narodowe w Krakowie, sygn. MNK VIII-kal.257. Zdjęcie: Pracownia Fotograficzna MNK

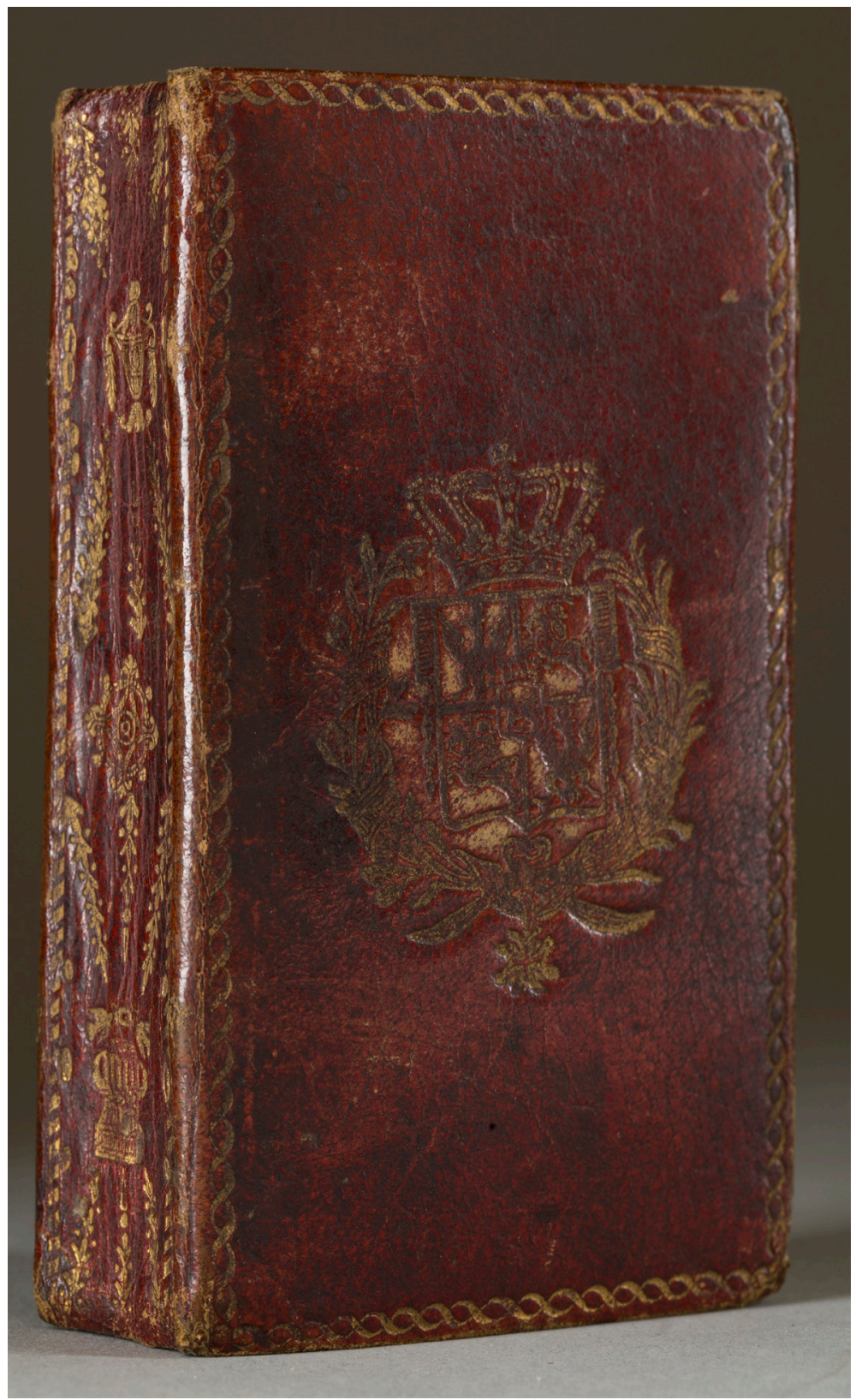


Fot. 6. Odręczna notatka I. Wolskiego, [w:] „Kalendarzyk polityczny na rok 1846”, wyd. F. Radziszewski, Warszawa [1845], k. [1r]. Źródło: Muzeum Narodowe w Krakowie, sygn. MNK VIII-kal.139. Zdjęcie: Pracownia Fotograficzna MNK

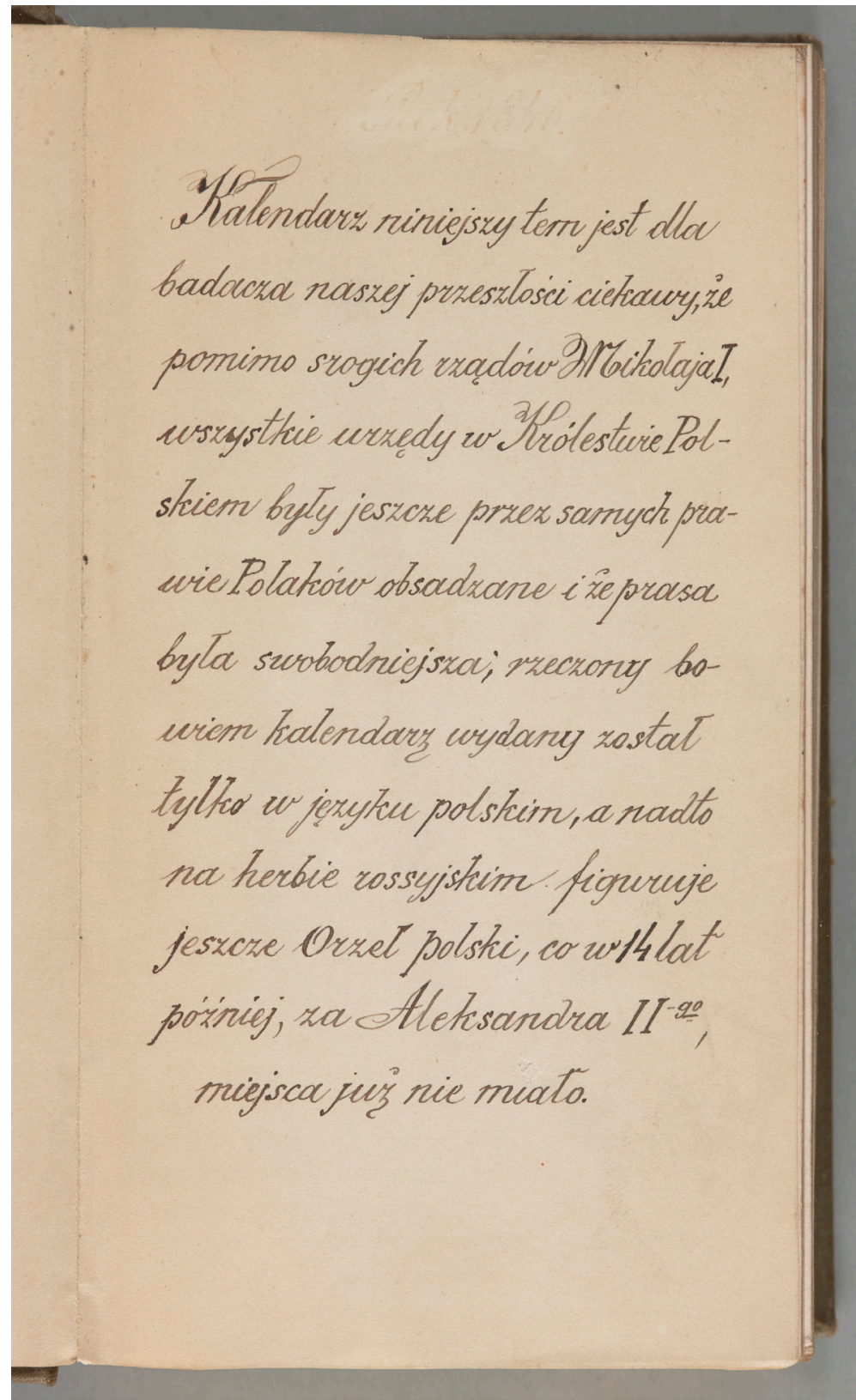


Fot. 7. „Przedświt. Kalendarz polski na rok zwyczajny 1906”, Warszawa 1906, okładka. Źródło: Muzeum Narodowe w Krakowie, sygn. MNK Biblioteka - II 1449 s.z. Zdjęcie: Pracownia Fotograficzna MNK

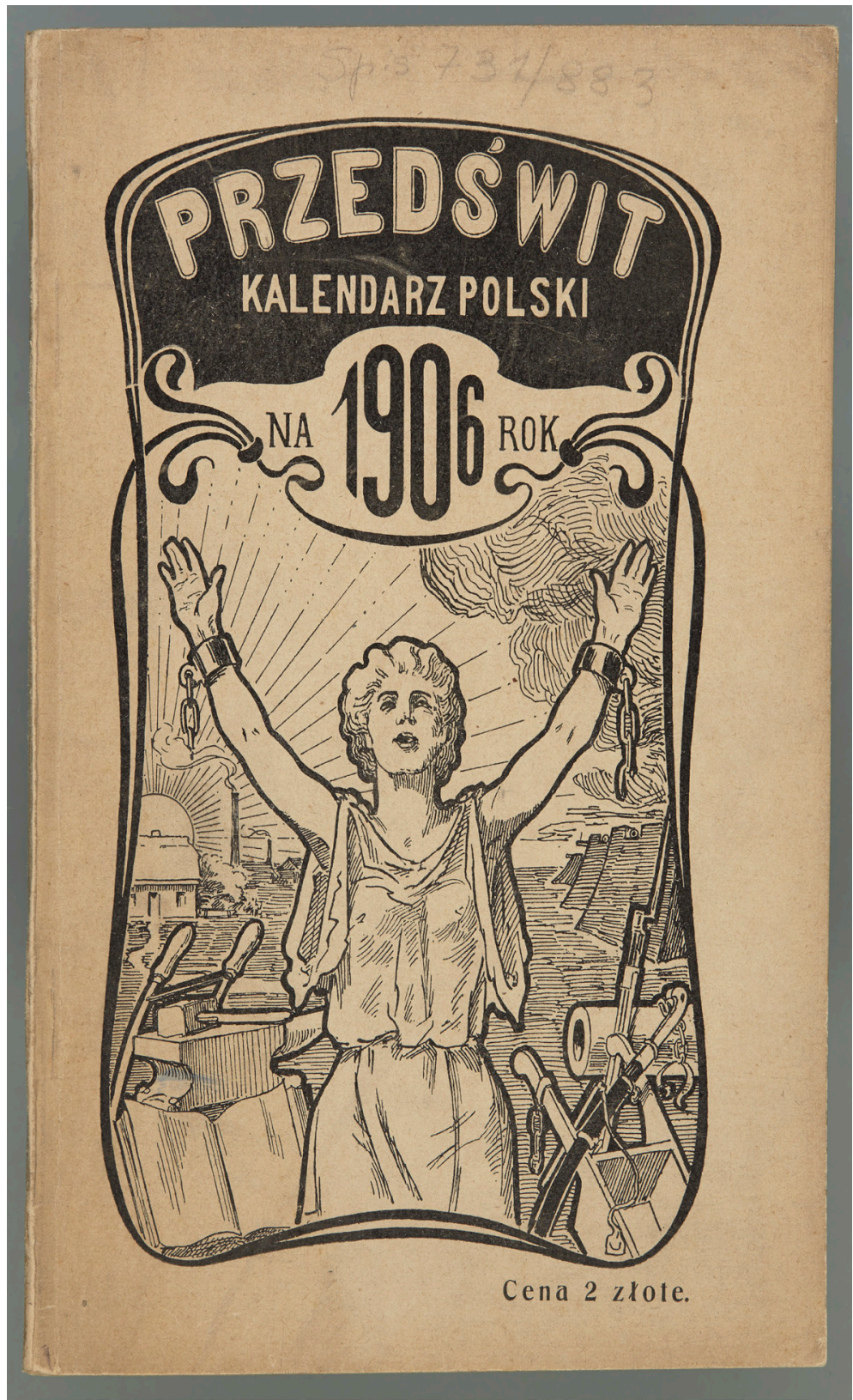


Fot. 8. Kalendarz ścienny na rok 1859 wykonany w Zakładzie ArtystycznoLitograficznym „Czasu” w Krakowie, ułożył i litogr. H. Walter. Źródło: Muzeum Narodowe w Krakowie, sygn. MNK III-ryc.20413. Zdjęcie: Pracownia Fotograficzna MNK

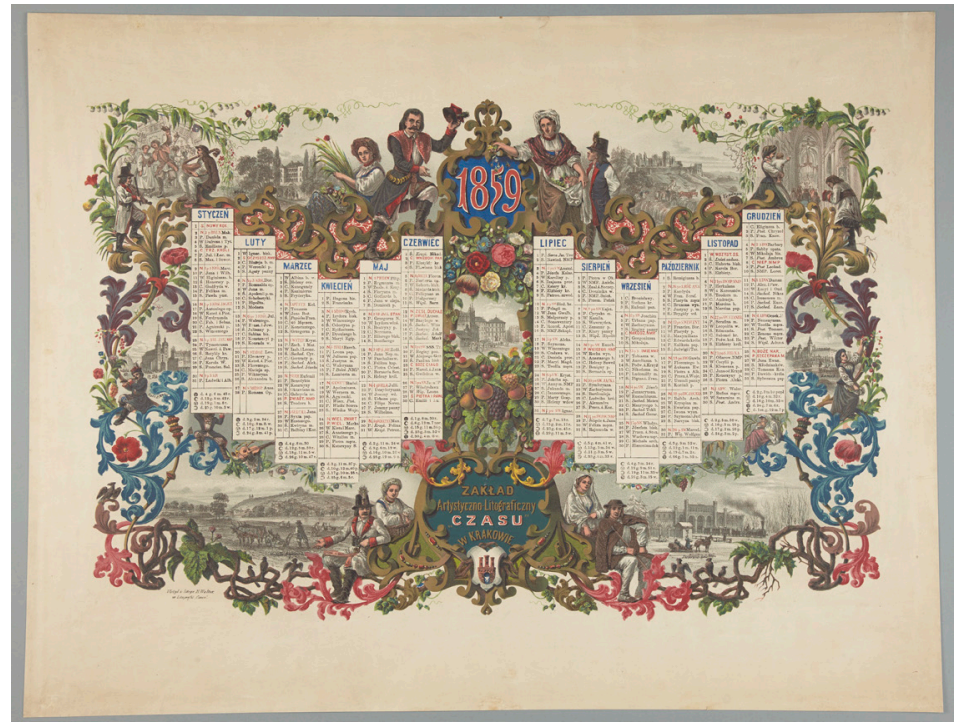

Fot. 9. Blankiet chromolitograficzny na kalendarz ścienny na rok 1861 wykonany w Zakładzie Artystyczno-Litograficznym „Czasu” w Krakowie, ryt. i litogr. W. Popelik. Źródło: Muzeum Narodowe w Krakowie, sygn. MNK III-ryc.22881. Zdjęcie: Pracownia Fotograficzna MNK

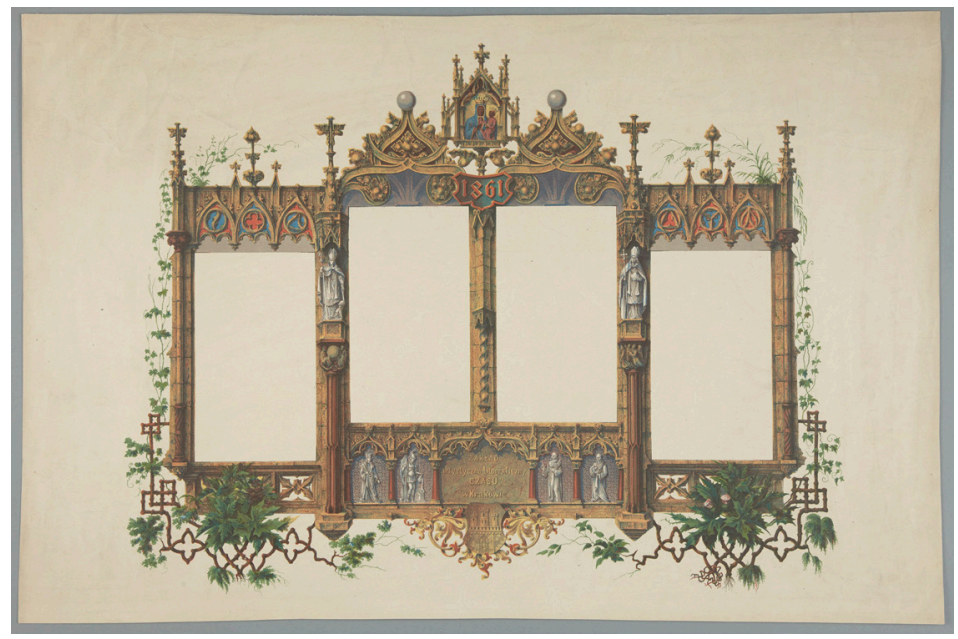


Fot. 10. Kalendarz ścienny na rok 1860 wykonany w Zakładzie ArtystycznoLitograficznym Maksymiliana Fajansa w Warszawie, według obrazu J. Simmlera. Źródło: Muzeum Narodowe w Krakowie, sygn. MNK III-ryc.20424. Zdjęcie: Pracownia Fotograficzna MNK

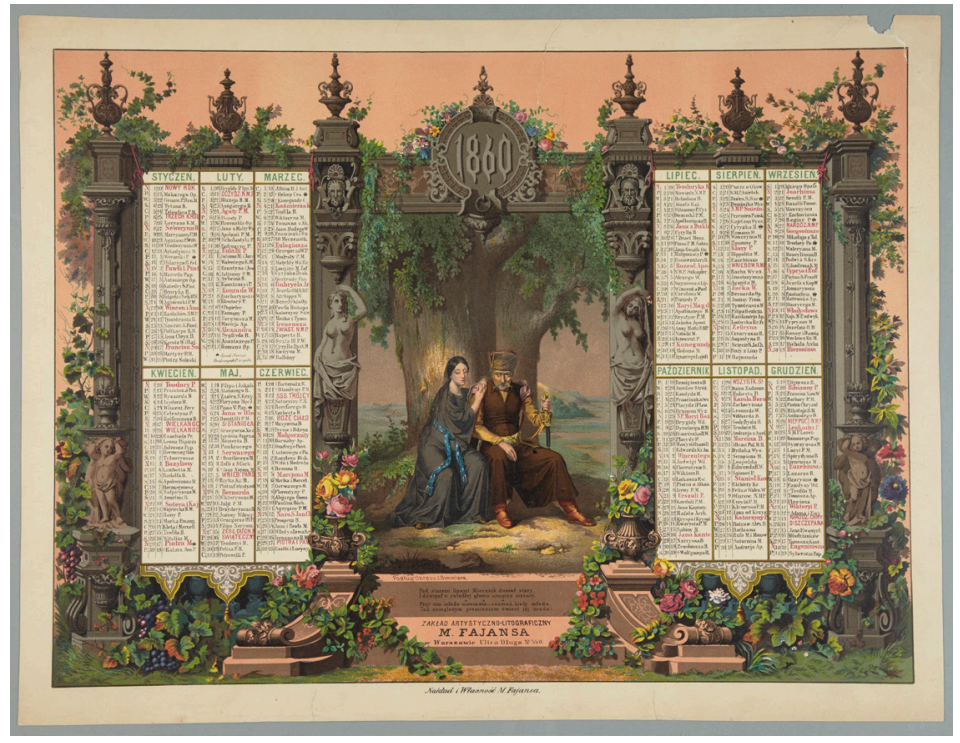

Fot. 11. Kalendarz ścienny fotograficzny na rok 1866 wykonany w Zakładzie Konrada Brandla i Spółki w Warszawie [online]. Źródło: Mazowiecka Biblioteka Cyfrowa. Dostępny w Internecie: http://mbc.cyfrowemazowsze.pl/dlibra/ docmetadata?id=4131 [dostęp 06.05.2019]

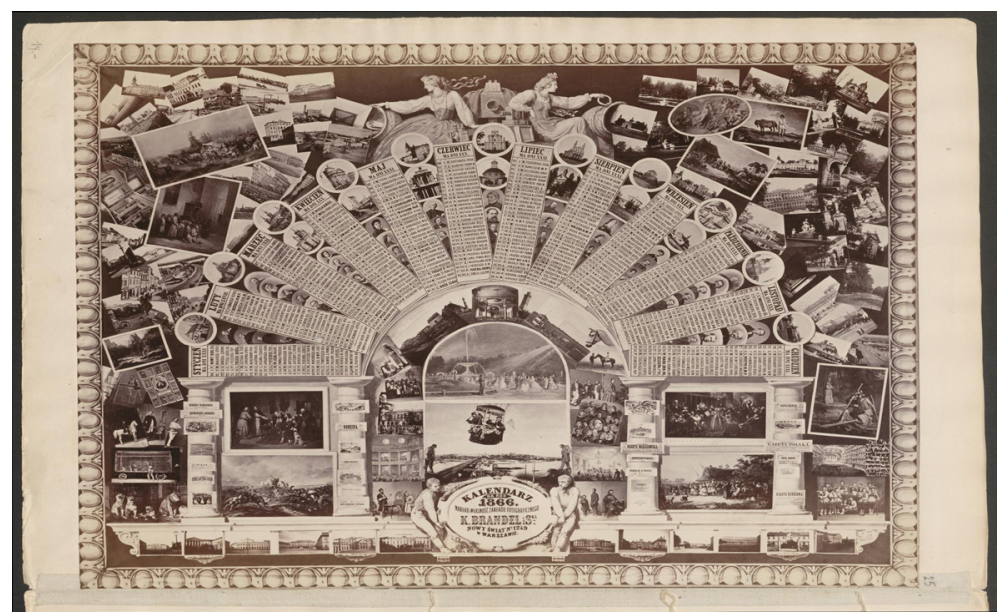

